\title{
1 \\ Universal and Particular: The Language of Plague, 1348-1500
}

\author{
ANN G CARMICHAEL
}

What disease or diseases caused the recurrent, demographically punishing epidemics that Europeans called plague? During the last twenty years a once prevalent historical consensus about causes and consequences of European plagues has dissolved, prompting new archival research as well as novel technological and interdisciplinary approaches to material evidence. The core debates about the history of plague are not, however, limited to scholars of medieval and early modern Europe. Molecular biologists over the last decade have determined that the organism that causes plague today, Yersinia pestis, is a relatively recent emergent pathogen descended from a significantly less lethal gastro-intestinal parasite, Yersinia pseudotuberculosis. Furthermore, fifty years ago microbiologists accepted a model of three different "biovars" — biochemically different variants - of Yersinia pestis, which were tidily aligned to three historical pandemic waves: antiqua, mediaevalis, and orientalis. That synthesis, too, is seriously challenged. There are instead at least eight Yersinia pestis strains and four biovars, and all have emerged within the last 5000 to 20,000 years. ${ }^{1}$ This organism remains a likely perpetrator of the great plagues in Europe because all Yersinia pestis biovars can be extraordinarily lethal in human bodies.

Most medievalists, including those who doubt that the Black Death and subsequent plagues could have been caused by Yersinia pestis, make a modern assumption that the Black Death indeed had some unique microbial cause. No one yet has argued in a sustained fashion that the plague was a "perfect storm" of many different epidemic infectious diseases, but one could. ${ }^{2}$ Nor has a radical scepticism emerged-for example, that the causes of each and every local or regional epidemic called peste/pestilentia by contemporaries need to be investigated separately, unrelated to other local contexts—but that, too, might be possible. If we would be truly rigorous, we cannot assume that a "plague" in one place was due to the same specific microbial cause as a pestilence in another locality, even

Professor Ann G Carmichael, History Department, Indiana University, 1020 E Kirkwood Avenue, 742 Ballantine Hall, Bloomington, IN 47405-7103, USA.

I am especially grateful to Vivian Nutton and to Lloyd and Dorothy Moote for their encouragements, and to the support of the (US) National Institutes of Health, 1G133LM8386-1.

\footnotetext{
${ }^{1}$ Mark Achtman, Giovanna Morelli, Peixuan Zhu, Thierry Wirth, Ines Diehl, et al., 'Microevolution and history of the plague bacillus, Yersinia pestis', Proc. Natl. Acad. Sci. USA, 2004, 101 (51): 17837-42. See also Kenneth L Gage and Michael Y Kosoy, 'Natural history of plague: perspectives from more than a century of research', Ann. Rev. Entomol., 2005, 50: 505-28; Dongsheng Zhou and 17 others, 'Genetics of metabolic variations between Yersinia pestis biovars and the proposal of a new biovar, microtus', J. Bacteriol., 2004, 186 (15): 5147-52; and the still useful review by Robert D Perry and Jacqueline D Fetherston, 'Yersinia pestis: etiologic agent of plague', Clin. Microbiol. Rev., 1997, 10 (1): 35-66.

${ }^{2}$ See the recent review by John Thielmann and Frances Cate, 'A plague of plagues: the problem of plague diagnosis in medieval England', J. Interdiscip. Hist., 2007, 37 (3): 371-93.
} 


\section{Ann G Carmichael}

during this worst of all recorded pandemics. There needs to be evidence for such a claim. During the High Middle Ages Europe was thickly settled, but profoundly rural; great cities were exceptional, and regional markets were not well integrated. ${ }^{3}$ In the early modern centuries, market centres were far better connected: a significant epidemiological difference. Scholars, nevertheless, analyse individually later medieval and early modern pestilences, accepting local differences and local historical contexts. Nor do most maintain that, given one location, all the sizeable pestilences over these later centuries were necessarily due to the same cause. Historians simply do not accept that "plague" (peste) had or has one universal translation applicable over both time and space-except when we consider the Black Death.

In other words, some of the doubts expressed in recent years are solely about Yersinia pestis as the cause of plagues in Europe, and do not contest the view that a single pathogen was principally responsible for the pan-European epidemic of 1347-50. Even more remarkably, there has been little doubt among the doubters that whatever microbe caused the Black Death also caused the next epidemic wave of the $1360 \mathrm{~s}$ - and so on. Plague language, both modern and medieval, thus begins with plague's universality.

\section{The Black Death: Contemporaries Confront a "Universal" Pestilence}

Survivors of the Black Death often claimed that it was a "universal plague" or "universal pestilence". "General mortality" was another characteristic phrase, one that occurred early on in hastily made wills and testaments of this pandemic. ${ }^{4}$ Universal pestilence differentiated this epidemic from more expected parameters of mortality, but the term did not carry the same meaning for all users. For physicians "universal" implied an explanatory cluster opposing "celestial—remote-universal" to "particular-terrestrialand proximate". 5 Among laymen a general or universal pestilence tended to mean that

\footnotetext{
${ }^{3}$ See David Nicholas, Urban Europe, 1100-1700, New York, Palgrave Macmillan, 2003, pp. 3-23; and Stephan R Epstein, Freedom and growth: the rise of states and markets in Europe, 1300-1750, London, Routledge, 2000, pp. 49-72.

4 "General" pestilence may have referred to the mortality occurring in all age groups, and I believe that it is more common among those places stricken before mid-1348. Studies of wills and testaments during this early period include Francine Michaud, 'La peste, la peur et l'espoir: le pèlerinage jubilaire de romeux marseillais en 1350', Le Moyen Âge, 1998, 104: 399-434; Shona Kelly Wray, 'Speculum et exemplar: the notaries of Bologna during the Black Death', Quellen und Forschungen aus italienischen Archiven und Bibliotheken, 2001, 81: 200-28; Richard W Emery, 'The Black Death of 1348 in Perpignan', Speculum, 1967, 42: 611-23; Christian Guilleré, 'La peste noire à Gérone (1348)', Annals de l' Institut d' Estudis Gironins, 1984, 27: 87-161; and Richard Francis Gyug, The diocese of Barcelona during the Black Death: the register Notule Communium 15 (1348-1349), Toronto, Pontifical Institute of Mediaeval Studies, 1994, pp. 3-74.

${ }^{5}$ D'Agramont and medical theories will be discussed briefly below. For general discussion of Jacme d'Agramont's treatise within the contemporary medical framework, see Jon Arrizabalaga, 'Facing the Black Death: perceptions and reactions of university medical practitioners', in Luis García-Ballester, Roger French, Jon Arrizabalaga and Andrew Cunningham (eds), Practical medicine from Salerno to the Black Death, Cambridge University Press, 1994, pp. 237-88. The treatise is translated and published by Charles E-AWinslow and M Duran-Reynals, 'Regiment de preservacio a epidimia o pestilencia e mortaldats', Bull. Hist. Med., 1949, 23: 57-89 (hereafter, d'Agramont, Regiment). Irma Naso surveyed medical aspects of plague literature, 'Individuazione diagnostica della "Peste nera", in La peste nera: dati di una realtà ed elementi di una interpretazione, Atti del Convegno storico internazionale 1993, Spoleto, Centro Italiano di Studi Sull'Alto Medioevo, 1994, pp. 349-81. The strictly contemporary plague treatises of medical men are surprisingly few. Naso counts only twenty medical reports across western Europe, some of which were quite brief.
} 
the pestilence was not confined to a social sector or age group, or that more than one region was involved. It was "everywhere", by which chroniclers included only their own region and the limited number of places they heard of through political or religious alliances.

Contemporaries necessarily described the great pestilence with words commonly used to report circumscribed epidemics in the thirteenth and fourteenth centuries. Italian chroniclers typically use mortalitas or the vernacular moria; more rarely one sees clades (destruction). Physicians typically used pestilentia, epidemia, and occasionally peste, but the word choice seems to have little significance. ${ }^{6}$ The words all conveyed a sense of large-scale mortality, without assigning any discrete or distinguishing characteristics other than death by illness. But despite the common words, this plague became something that occurred everywhere, and to which everyone was at risk. The great humanist Francesco Petrarca summarized the language of universality that emerged in the wake of the great pestilence: "The word 'plague' had been heard and read about in books; a universal plague that was to empty the world had never been seen or heard of." "While the immediate survivors of the Black Death wrote within a shared, pre-existing culture, and chroniclers chose similar terms to describe the events that they witnessed, what we now call the Black Death was not a traditional pestilence. Within some finite period of time after the great mortality became part of their past, survivors began to characterize its distinctiveness from other epidemics. ${ }^{8}$ A break with past tradition occurred, even if the same terms were used before and after the divide.

In an extensive, careful survey of Italian, French, and German chronicles which were written during the mortality, Gabriele Zanella reviewed the classical and medieval sources to which the best known survivor narratives of the 1348 plague related. ${ }^{9}$ He observed that sustained consideration of the epidemic was quite rare in works written during 1348 or 1349. Zanella further emphasized that contemporary reports made in localities that were hit early were all situated within a larger context of crises-famines, war, earthquakes, and epidemic - and that the special place of this particular epidemic among the aspects of the great mortality did not coalesce until some time later. What he called a topos for the plague emerged afterward and helped to bring some uniformity to disparate experiences over the plague years. Some of the principal features common to the immediately post-plague

\footnotetext{
${ }^{6}$ For contemporary Hebrew terminology, see Ron Barkai, 'Jewish treatises on the Black Death (1350-1500): a preliminary study', in Roger French, Jon Arrizabalaga, A Cunningham (eds), Medicine from the Black Death to the French Disease, Aldershot, Ashgate, 1998, pp. 6-25. On Arabic terminology, see Lawrence I Conrad, 'Ta'un and Waba': conceptions of plague and pestilence in early Islam', J. Econ. Soc. Hist. Orient, 1982, 25 (3): 268-307. In general, see Arrizabalaga, op. cit., note 5 above, pp. 242-44. Epidemia and pestilentia did, however, take physicians to different bodies of medical literature.

${ }^{7}$ Petrarca, Letters of old age [Rerum senilium libri], ed. and trans. Aldo S Bernardo, Saul Levin, and Reta A Bernardo, 2 vols, Baltimore, Johns Hopkins University Press, 1992, vol. 2, p. 372.

${ }^{8}$ For example, a great plague in Florence in 1340 evoked traditional frameworks in the work of the chronicler Giovanni Villani. See Louis Green, Chronicle into history: an essay on the interpretation of history in Florentine fourteenth-century chronicles, Cambridge University Press, 1972, pp. 13, 37; many examples can be found throughout Alfonso Corradi, Annali delle epidemie occorse in Italia dalle prime memorie fino al 1850, 5 vols, repr. Bologna, Forni, 1972-1973.

${ }^{9}$ Gabriele Zanella, 'La peste del 1348: Italia, Francia e Germania: una storiografia a confronto', in La peste nera, op. cit., note 5 above, pp. 49-135, rpt. online: http://www.gabrielezanella.it/Pubblicati/Todi93/Todi93.pdf, where the pagination begins with p. 1. I will use the pagination of the online version. To make his task manageable, Zanella omitted the Biblical and apocalyptical traditions and did not confront plague in medical texts, because a companion article by Irma Naso addressed that aspect of plague literature, op. cit., note 5 above, pp. 349-81.
} 


\section{Ann G Carmichael}

accounts were: plague was general and/or everywhere; it was rapid or suddenly lethal, and thus was frequently described as contagious; it was inevitable, insofar as preparations taken to avoid it were usually unsuccessful; the disease itself was previously unknown, and thus physicians had no remedies; its effects were indescribable, that is, survivors felt that they could not fully capture in words what had happened; and the epidemic persisted for months in any given locality. ${ }^{10}$

Zanella brings to the foreground important discontinuities in plague accounts. Most medievalists instead find continuities in medieval themes and traditions more striking. Medical and religious ideologies were particularly resilient. For example, Jon Arrizabalaga's now classic study of medical treatises produced during the plague years emphasizes the continuity of Black Death medical accounts with traditional medieval medicine. At the time, physicians found no way to classify the exceptional nature of the pestilence, though it is important to note few medical treatises were actually written in the eye of the storm. ${ }^{11}$ We can see something of the determined framework of medieval epidemiological explanation in two of the treatises written before mid-1348 - that of Jacme d'Agramont and Gentile of Foligno. ${ }^{12}$ Both men died of plague before the end of June. Gentile of Foligno provided the best and classic example of an academic practitioner who initially assumed that the pestilence was like one he had seen before or maybe others he had read about. Shortly before his own death, he decided that this plague was an event without comparison. $^{13}$

Meanwhile physicians' observations of the clinical signs of plague did not fit readily within a pre-existing nosological category. Medical tradition concerning plague would change later in the fourteenth century to accommodate particular features of these epidemics that distinguished them from what was previously known. ${ }^{14}$ But did medical thinking change in any fundamental way as a result of the Black Death? Irma Naso, in a companion survey to Zanella's, also acknowledges that this epidemic was different from previous medieval pestilences. It was the first to prompt violent individual and collective responses, and it was the first to elicit physicians' admission of ignorance and impotence

\footnotetext{
${ }^{10}$ Zanella, op. cit., note 9 above, pp. 16-17. I found too late Jussi Hanska's Strategies of sanity and survival: religious responses to natural disasters in the Middle Ages, Helsinki, Finnish Literature Society, 2002, with which study I might have made some correction to several particulars of my argument and examples.

${ }^{11}$ Arrizabalaga, op. cit., note 5 above. The few contemporary plague treatises of medical men are summarized and reviewed by Dominic Palazzotto, The Black Death and medicine: a report and analysis of the tractates written between 1348 and 1350, University of Kansas dissertation, Ann Arbor, University Microfilms, 1973, who translates substantial portions of each treatise.

${ }^{12}$ Arrizabalaga, op. cit., note 5 above, pp. 240-1. Charles E-A Winslow and M Duran-Reynals, 'Jacme d'Agramont and the first of the plague tractates', Bull. Hist. Med., 1948, 22: 747-65, misunderstand the importance of d'Agramont's discussion of universal versus particular corruption of the substance of the air, so Arrizabalaga provides a necessary corrective. On Gentile of Foligno, see also Lynn Thorndike, A history of magic and experimental science, 8 vols, New York and London, Columbia University Press, 1923-58, vol. 3, pp. 241-6.

${ }^{13}$ Arrizabalaga, op. cit., note 5 above, p. 247 and n. 36; and Naso, op. cit., note 5 above, pp. 356-61. Gentile of Foligno's 'Consilium primum magistri gentilis de pestilentia' is provided by Karl Sudhoff, 'Pestschriften aus den ersten 150 Jahren nach der Epidemie des "schwarzen Todes" 1348', Archiv für Geschichte der Medizin, 1912, 5: 332-5; to the point here: “. .. haec pestilentia sive epidimia sive quo nomine nominetur est multum verenda nec audita nec visa in libris ...", p. 332.

${ }^{14}$ Best illustrating this claim is Melissa P Chase, 'Fevers, poisons and apostemes: authority and experience in Montpellier plague treatises', Ann.N.Y. Acad. Sci., 1985, 441: 153-69. Arrizabalaga, op. cit., note 5 above, allows the general argument that the philosophical framework of plague treatises changed after 1350 .
} 
before it. Medical accounts of subsequent plagues, however, did not so readily summon such professional disclaimers. Naso argues that physicians acknowledged the novelty of plague, but determinedly forced their later experience and observations into accepted medical categories, in particular aligning kinds of peste with kinds of fevers. Therefore she feels it more important that we understand that medical reflections illustrate deep and abiding continuities across the late medieval centuries. Academic medical tradition about plague rebounded, remaining essentially and consistently Galenic, unbroken down to the sixteenth or seventeenth centuries.

Rosemary Horrox, assembling and translating some of the most cogent testimonies of eyewitnesses and survivors, similarly stresses continuity, pointing to the longer, unbroken socio-religious context of plague as punishment for sin. While Horrox allows that after the Black Death "the world could never have been quite the same again", that fact did not prevent secular and religious authorities from trying to impose a return to established verities. ${ }^{15}$ Even after the loss of over one-third of Europe's overall population, the prevailing view that all great pestilences were punishment for human sins and crimes is a mantra in plague accounts down to the seventeenth century. Horrox also does not see a novel, emergent literary construction in chroniclers' accounts of plague, but instead a miscellany of "verbal clichés" that survivors used to capture their incredulity at the scale of the first epidemic. Tradition reasserts its power in English records by accommodating subsequent pestilences as expected punishments, even when the recurrences caused demographically severe losses. Interestingly, she points out that we selectively isolate accounts of the late 1340s and 1350s that mention plague, and thereby suppress evidence that plague may not have had a universally horrific impact. ${ }^{16}$ This is a very important warning that modern assumptions about the geographical universality of the Black Death may distort our retrospective epidemiological assessment.

Explaining why this plague was different from others depended upon explaining how plague could be general and universal. There are two principal medieval idea systems that gave specific non-modern meanings to the term "universal plague". Universal plague was for medical men categorically distinct from pestilences attributable to terrestrial (or " proximate", or local/environmental) factors. This plague occurred everywhere, not within circumscribed socio-economic zones-such as city or countryside. It could not be explained solely with reference to the operations of the four elements, or to ordinary disease causation by imbalance or disturbance of the four humours; its causes were remote, proceeding from the stars. For medical authorities celestial events triggered plague. For Church authorities and for many pious laymen, on the other hand, the universal plague was satisfactorily explained by the universality of human sin, either in the 1340 s because of the weight of sins at the time, or generally part of the human condition, consequent to the Fall and the expulsion from Eden. Individual sins were not individually punished in a universal plague. Universal punishment had both Biblical precedents and apocalyptical significance.

\footnotetext{
${ }^{15}$ Rosemary Horrox (trans. and ed.), The Black Death, Manchester University Press, 1994, p. 247.

${ }^{16}$ Ibid., pp. xii, 4. "Verbal clichés" included unburied bodies and their overwhelming stench, entire families wiped out, survival rates under one in five, or even one in ten.
} 


\section{Ann G Carmichael}

\section{Physicians and Universal Pestilence}

The physicians' case for universality relied on an assumption that celestial events could, through a series of intermediate changes, corrupt the substance of one or more of the four elements. For most physicians the "substance" of the element "air" was altered such that it could draw up pestilential vapours from polluted waters and places. ${ }^{17}$ But then it became quite complicated to explain the differential spread of plague over time and space. Jacme d'Agramont, who provided medieval laymen with an atypically systematic and thorough explanation of medical thinking, held that "every plague begins in one region" and was conveyed from place to place in a variety of ways. ${ }^{18}$

To achieve a universal pestilence, some universal change had to facilitate the appearance of plague in many localities. A universal pestilence differed from an epidemic, which had local causes. A celestial event was large enough to affect all regions, but how could its deleterious effects persist everywhere while staggering its local appearances? The most familiar account of the universality of plague as a distinguishing characteristic is the consilium written in October 1348 in Paris by the medical faculty for the king of France. ${ }^{19}$ Yet the conjunction of Jupiter, Saturn and Mars, in March 1345, was not a completely simultaneous conjunction of these planets, and furthermore became only in retrospect the astrological event portending a great plague. ${ }^{20}$ It was not even one of the "greater" conjunctions, which only occurred every 240 years when the planetary cluster first entered a new "triplicity" of the zodiac. In their consilium the medical faculty therefore acknowledged that the celestial events of 1345 "cannot explain everything we would wish", and necessarily provided details of other exacerbating factors, both celestial and terrestrial. At the moment when they were writing, the plague had not yet reached Paris, and they could still offer reassurance that with improvement in weather conditions the pestilence might not be as punishing as it was further south. ${ }^{21}$ Most physicians, including the counsellors in Paris, were also careful to note that celestial events did not absolutely determine particular effects among humans. (All of the monotheistic religions reserved an important role for human free will.)

Because the conjunction had occurred three and a half years earlier than the plague, and was both predicted and studied before 1345, why were no measures taken to avoid a great pestilence? The answer involves further astrological technicalities, including that any disease effects were expected mostly in the immediate aftermath of the conjunction. Delayed effects were expected to be political and religious, and to occur ten to thirteen

\footnotetext{
${ }^{17}$ Arrizabalaga, op. cit., note 5 above, esp. pp. 248-59.

${ }^{18}$ D'Agramont, Regiment, p. 62 . Zanella, op. cit., note 9 above, makes a particular point of the fact that the plague did not strike all at once, and that some were blindsided while others were only receiving the news of plague far away, see pp. 53-4.

${ }^{19}$ Horrox (trans. and ed.), op. cit., note 15 above, pp. 158-63.

${ }^{20}$ See John D North, 'Astrology and the fortunes of churches', Centaurus, 1980, 24: 181-211; and Bernard R Goldstein and David Pingree, 'Levi ben Gerson's prognostication for the conjunction of 1345', Trans. Am. Philos. Soc., 1990, 80 (6): 1-60; I am most grateful to Professor William Newman and Professor Gerrit Bos for these references. See also Arrizabalaga, op. cit., note 5 above, pp. 252-6, on the link between physicians' use of astrological events when speaking of "universal pestilence" in 1348.

${ }^{21}$ Horrox (trans. and ed.), op. cit., note 15 above, p. 158.
} 
years later. ${ }^{22}$ In other words, at the time of the epidemic, not only were there both theological and astrological problems when blaming the epidemic on the prior conjunction, the emerging temporal and spatial facts of the epidemic's progression made explanations based on a discrete celestial event more complex.

After the plague, the conjunction became an attractive explanation for the ubiquity of pestilence, but not all agreed that it sufficed. Conrad of Megenberg felt the need to dismantle arguments that the conjunction could ever have caused the plague directly. ${ }^{23}$ Conrad also in 1349 took an unusual approach, claiming that the true action of the conjunction was to release vapours from the earth in a great earthquake, which had in fact occurred at the beginning of $1348 .{ }^{24}$ Writing in 1349 or later, both Simon of Covino and Geoffrey de Meaux composed slightly different astrological treatises than those of the Paris doctors, both shifting the balance of explanation toward the greater powers of the sun and moon in order to account for the unprecedented and widespread violence of the epidemic. $^{25}$ Some even considered the physicians' general explanation absurd. Petrarca later, in withering attacks, would ridicule the astrologers' predictions as so many selfserving falsehoods. Calling them charlatans, about their just-in-time predictions of new evil influences in the 1360s Petrarca warned,

But for us it ought to be no less sure today than in the future, if we recall their promises of old. Well, [the doctor-astrologers] maintain that Mars and Saturn are coming together somewhere among the stars and that conjunction — to use their word—after the year's end [1361] will last for a full two years. Quite astonishing that from the beginning of things stars have never been in these locations as long as they have travelled their courses throughout the heavens! ... We do not know what is happening in the heavens, but impudently and rashly they profess to know... . For they are going to say this and any nonsense at all rather than confess their own ignorance. Theirs is not only

\footnotetext{
${ }^{22}$ Gerrit Bos, 'R. Moshe Narboni: philosopher and physician, a critical analysis of Sefer Orah Hayyim', Medieval Encounters, 1995, 1 (2): 219-51, pp. 242-3. Narboni, a most learned physician, accepted the astrological framework and reconciled prediction with realities around 1350: "This disease already roams about in all parts of human settlement, but has not yet turned aside to the corners of the West. It started immediately after the conjunction of Saturn and Jupiter."

${ }^{23}$ See the treatise edited by Sabine Krüger, 'Krise der Zeit als Ursache der Pest? Der Traktat De mortalitate in Alamannia des Konrad von Megenberg', in Festschrift für Hermann Heimpel. Veröffentlichungen des MaxPlanck-Instituts für Geschichte, Göttingen, Vandenhoeck and Ruprecht, 1972, vol. 2, pp. 839-83, on pp. 865-6. Conrad argues that Saturn, the more malevolent planet, remains in a house for only two and a half years, and that the mortality lasted five to six years at least. Petrarca is far less generous to the astrologers, ridiculing them at every opportunity. See Petrarca, op. cit., note 7 above, vol. 1, p. 81 .

${ }^{24}$ Dagmar Gottschall, 'Scienza in volgare: Corrado di Megenberg e la peste del 1348', in Nadia Bray and Loris Sturlese (eds), Filosofia in volgare nel medioevo, Atti del Convegno della Società Italiana per lo Studio del Pensiero Medievale, Lecce, 2002, Louvain-la-Neuve, Fédération internationale des instituts d'études médiévales, 2003, pp. 107-31. Conrad wrote a Latin treatise in 1350 or later, at the request of a cardinal in Avignon, and there more deliberately tried to accommodate and extend the Paris commentary. He was a canon in Regensburg who knew of the great earthquake and that plague deaths in southern German lands seemed to spread from the direction of the earthquake, rather than from the sea.

${ }^{25}$ Horrox (trans. and ed.), op. cit., note 15 above, pp. 163-72. See also Arrizabalaga, op. cit., note 5 above, pp. 252-4, who briefly discusses the astrological reflections of Alfonso of Cordoba and Jacme d'Agramont. Chase, op. cit., note 14 above, pp. 155-6, discusses Alfonso of Cordoba's reaction to the Paris masters in further detail. Discussion of the difficulty of fitting astrological explanations to the facts of the plague seems to have been particularly acute in Avignon and Montpellier.
} 


\section{Ann G Carmichael}

ignorance but blindness and total madness, which many times in the past was evident to everyone, but never more clearly than during this present plague. ${ }^{26}$

Petrarca here pointed to the new historical times in which they were living after the plague. Some physicians would take an historical approach, and scavenge ancient authorities to find comparable pestilences.

At the time of the Black Death, physicians also needed to explain how the star-generated pestilence clearly moved from one place to another. The "stinking breath of the wind" provided one vehicle for spreading a corruption, as well as an explanation more accessible to less scientifically minded audiences. ${ }^{27}$ Natural philosophers were quite unclear about the motions and physical actions of the winds involved. What passes for fourteenth-century academic "meteorology" not only attempted no practical relationship to farming or sailing, physicians made no effort to integrate physical principles discussed in commentaries on Aristotle's Meteorologia with Hippocratic/Galenic medicine. ${ }^{28}$ They neither sought nor saw larger geographical patterns of winds. Indeed, even the general scholastic debate was about the origin and natural place of air that moved in and around the element "earth". ${ }^{29}$

Pestilential winds were almost as imperceptible as the actions of celestial bodies. Explaining the traditional wisdom about great pestilence, d'Agramont felt that winds linked medical and Biblical wisdom, and provided a mechanical means of distributing air corrupted in its substance or qualities. ${ }^{30}$ The Paris masters pointed to unseasonable and frequent "gusts of wind in the wild southerly gales", which were to northern climes "alien vapours". "31 Because winds were more diagrammed than mapped, tracing the path of plague over geographical space was not their analytical objective. Rather mapping linked physicians' most general observations to apocalyptical treatises by diagramming the great plan of creation. The control that maps exerted was over time rather than space. ${ }^{32}$

${ }^{26}$ Petrarca, op. cit., note 7 above, vol. 1, pp. 80-1, to Boccaccio.

27 "Stinking breath of the wind" comes from Petrarca's closest friend, Louis Sanctus [or Heyligen] of Beeringen, a musician in the papal court at Avignon. See the translated text in Horrox (trans. and ed.), op. cit., note 15 above, pp. 41-5, on p. 42, and note 36 below for a recent critical edition. He died in the second plague pandemic.

${ }^{28}$ Sylvie Bazin-Tacchella, 'Considérations sur l'air, le temps et les saisons dans la Chirurgia magna de Guy de Chauliac', in Claude Thomasset and Joëlle Ducos (eds), Le temps qu' il fait au Moyen Âge: phénomènes atmosphériques dans la littérature, la pensée scientifique et religieuse, Cultures et Civilisations Médiévales, XV, Paris, Université de Paris-Sorbonne, 1998, pp. 15-29.

${ }^{29}$ See here David Alexander, 'Dante and the form of the land', Ann. Assoc. Amer. Geogr., 1986, 76 (1): 38-49; Joëlle Ducos, 'Théorie et pratique de la météorologie médiévale: Albert le Grand et Jean Buridan', in Thomasset and Ducos, (eds), op. cit., note 28 above, pp. 45-58; and Stuart Jenks, 'Astrometeorology in the Middle Ages', Isis, 1983, 74 (2): 185-210. Though on a much earlier period, Barbara Obrist, 'Wind diagrams and medieval cosmology', Speculum, 1997, 72: 33-84, esp. pp. 75ff, is useful. The path of plague did not even work well with the traditionally understood movement of winds, but then both the diagrams of winds and their relationship to the physical world were problematic, because they both contributed to the stability of the greater cosmic order and, as in the case of plague, caused vast instability within the world; they breach the boundary between microcosm and macrocosm.

${ }^{30}$ D’Agramont, Regiment, pp. 64-6.

${ }^{31}$ Horrox (trans. and ed.), op. cit., note 15 above, p. 161. Probably these larger weather patterns were not observable until evidence on tides and winds began to be compiled for maritime users in the later Middle Ages.

${ }^{32}$ Laura A Smoller, 'Of earthquakes, hail, frogs, and geography: plague and the investigation of the Apocalypse in the Later Middle Ages', in Caroline Walker Bynum and Paul Freedman (eds), Last things: death and the Apocalypse in the Middle Ages, Philadelphia, University of Pennsylvania Press, 2000, pp. 156-87. 


\section{Universal Human Sin}

Medical discussion passively accommodated the religious tenet that the whole world could be affected because of the weight and universality of human sin. Most lay discussion of the event began and ended with punishment for sin, both before and immediately after the great pandemic. For example, Marco Battagli (in Rimini) summarized the familiar explanation, found in most lay accounts of the 1348 mortality: "By the year AD 1348, human iniquity and every manner of sin so expanded over the earth that its fetor and noise reached the just ears of the Almighty. Then His just wrath fell ...". ${ }^{33}$ A poet in Würzburg during the first half of 1348 tacked rumours of plague unfolding to his view that sin was something humans had control over: "I wish to lament a further calamity, because the truth is being hushed up while we are all wallowing in sin at a time of great miracles; namely, that old and young are now dying and none can defend himself.",34

Ultimately all pestilences came from God. This was undisputed. But the problem with this universal aspect of a universal pestilence was proportionality. It required the more global framework: why just then? Why everyone? Guglielmo Cortusio wrestled with the implications of a capricious, punishing God, who surely did not want the death of sinners, and thus must have sent the plague to Tartars and Turks in order to give Christians a fair warning. The plague that came had to be likened to the Biblical plagues of Egypt, King David, and Ezechiel, and that in the time of Pope Gregory the Great. But as this pestilence uniquely spanned the whole world, ultimately it would be compared to the Great Flood. ${ }^{35}$ Petrarca was not convinced by such logic: "I do not deny that we deserve these things and even worse; but our ancestors also deserved them ... why is it that the violence of [God's] vengeance lies so extraordinarily upon our times? ... We have sinned as much as anyone, but we alone are being punished.",36

\footnotetext{
${ }^{33}$ Marco Battagli da Rimini (1312-1354), Marcha, ed. Aldo Francesco Massèra, Rerum Italicarum Scriptores (hereafter R.I.S.), new ed., vol. 16, part 3, Città di Castello, S. Lapi, 1912-13, pp. 54-5, though I here used the earlier edition: Breviarium Italicae historiae a temporibus Friderici II Augusti usque ad annum мCCCLIV ab anonymo Italo, sed synchrono, auctore consctriptum, ed. Ludovico Antonio Muratori, R.I.S., orig. ed., vol. 16, pp. 285-6; and see Green, op. cit., note 8 above, pp. 34-45, for extensive treatment of Giovanni Villani, who died in the plague, and the important post-plague chronicles of his brother, Matteo Villani, and of Marchionne di Coppo Stefani.

${ }^{34}$ Stuart Jenks, The Black Death and Würzburg: Michele de Leone's reaction in context [Yale University dissertation, 1976], Ann Arbor, University Microfilms, 1976, pp. 34-5, fn. 60. Jenks here translates a poem of Lupold Hornburg, in his 'General Sermon about the world's cares and troubles: how or why they come to pass', which he can precisely date between January and June 1348. Hornburg knows with some precision about the high mortality in Marseilles and Avignon, thus is probably writing no earlier than April. Diana Wood argues that Pope Clement VI publicly and officially emphasized the plague was caused by sin, but privately ordered autopsies and the reflections of astrologers; see Clement VI: the pontificate and ideas of an Avignon pope, Cambridge University Press, 1989, pp. 66-7.

${ }^{35}$ Guillelmi de Cortusiis, Chronica de novitatibus Padue et Lombardie, ed. Beniamino Pagnin, R.I.S., new ed., vol. 12, part 5, Bologna, Nicola Zanichelli, 1941-9, pp. 120-1: "De clade inaudita. Deus omnipotens qui non vult mortem peccatoris, sed ut convertatur et vivat, primo minatur, secundo vero percutit ad correctionem humani generis, non interitum. Volens affligere humanum genus plagis maximis, inauditis, primo in extremis partibus mundi, in orientis plaga cepit suum iudicium horrendum. Cum vero jam percussisset Tartaros, Turcos et genus infidelium universum ...", and then gave a second warning with the earthquake.

${ }^{36}$ Petrarca, Letters on familiar matters [Rerum familiarum libri], trans. Aldo S Bernardo, Albany, NY, State University of New York, 1975, book vIII, 7, p. 417, another letter to his "Socrates", Louis Sanctus. See here Jan Papy, "Creating an "Italian" friendship: from Petrarch's ideal literary critic "Socrates" to the historical reader Ludovicus Sanctus of Beringen', in Karl A E Enenkel and Jan Papy (eds), Petrarch and his readers in the Renaissance, Leiden and Boston, Brill, 2006, pp. 13-30.
} 


\section{Ann G Carmichael}

After Giovanni Villani died in the plague, Matteo Villani continued his brother's chronicle, and also tried to make sense of the calamity:

It is set down in Holy Writ that, sin having corrupted all the ways of man's flesh, God sent the flood over the earth; and, through his mercy, preserving humankind [through] Noah ... Since then, as in time people have multiplied, there have been several individual floods, plagues, infections and pestilences, famines and many other ills that God has permitted to afflict men for their sins. But from what one can gather from written records, there has been from the general flood till now no universal judgment of plague so all-embracing as that which came in our day. ${ }^{37}$

Matteo resolved to write at least annually of events, "so that in times to come a surer testimony to them may be had". Moralistic and gloomy, Matteo's chronicle delivers, according to Louis Green, "a tendency to re-examine the realities of the situation in the wake of the all-transforming shock of the plague". Similar sentiments appear in two of the very few histories written to summarize the plague's lesson, the famous Historia de morbo of Gabriele de' Mussis, and Conrad of Megenberg's Buch der Natur. ${ }^{38}$

To link universal sin to a universal pestilence, many compared the plague to the Biblical flood. Yet that comparison could border on heresy. Medieval philosophers and astrologers (especially Albertus Magnus) had speculated about great celestially caused floods involving elements other than water, including a flood of fire (diluvium ignis). Since there was no Biblical precedent for another pre-apocalyptical destruction of humanity comparable to the Great Flood, the astrology-based theory of diluvium ignis was condemned by the bishop of Paris in 1277. Afterwards, few pursued this kind of astrological prediction openly, but the Black Death may well have reopened discussion. Conrad of Megenberg knew there was a problem here, but argued that "universal" calamities such as the flood came directly from God. He thus rejected making the Great Flood and the pestilence equivalent, and instead advanced a novel naturalistic theory: terrestrial exhalations from the great earthquake of 1348 were for him the true cause of the universal-seeming plague. ${ }^{39}$

\section{Problems with the Black Death as a "Universal" Pestilence, Then and Now}

In general those who used the framework of universal pestilence to summarize events of the late 1340s encountered disconfirming empirical evidence, some of which was fitted to the emergent plague topos only with great difficulty. In this section I will discuss briefly two very different ways in which the lived experience of the Black Death sat uncomfortably with larger cosmologies about how the world was supposed to work. One of these involved the already mentioned claim that the epidemic afflicted the whole world. Modern authorities often accept this assertion about the geographical extent of the epidemic fairly

\footnotetext{
${ }^{37}$ Trans. by Green, op. cit., note 8 above, p. 44.

${ }^{38}$ Ibid., p. 45. For Gabriele de' Mussis, see Horrox (trans. and ed.), op. cit., note 15 above, pp. 14-26; the Würzburg cleric Michele de Leone's Chronicle of the times of modern men was begun as pestilence raged all around Würzburg, but seems, like Matteo Villani's similarly started chronicle, to place plague within the larger context of lugubrious events. See Jenks, op. cit., note 34 abve, p. 12.

${ }^{39}$ Roland Hissette, 'Albert le Grand et l'expression "diluvium ignis", Bulletin de Philosophie Médiévale, 1980, 22: 78-81. Marco Battagli is one of those who nevertheless believed that a destruction by fire (hence the great fever of plague) was predicted by Scripture; see Battagli, op. cit., note 33 above, p. 54.
} 
uncritically, and use it to support doubts that Yersinia pestis could have been the plague's cause. The other claim related specifically to apocalyptical predictions and the particular geography of plague's spread and virulence for contemporaries of the Black Death, which helped to support their sense of the end of days unfolding. The problem with that understanding of universal time was apparent when the world in fact did not end. A universal punishment for sin was not easily explained outside the warnings related to the last days.

\section{Temporal and Spatial Variations: The Path of the Plague}

The supposed universality of plague experience presented plague survivors with some puzzles. ${ }^{40}$ Universal for physicians did not imply simultaneous, and so they were not troubled that the plague did not hit the whole world all at once. Written in April 1348, d'Agramont's treatise, for example, began with reports of plague from the surrounding countryside; people were already terrified because of its unusual symptoms. ${ }^{41}$ The plague did not completely creep up unnoticed on Lerida (in Aragon), for its approach was observed. Gentile of Foligno's plague advice, written at the same time in Umbria, similarly reported plague unfolding elsewhere, lending a sense that the disease was grounded and mobile, travelling at an observable pace. ${ }^{42}$

Chroniclers attached more importance to the fact of non-simultaneity of plague within their own regions. Travellers, merchants and refugees carried information of plague elsewhere, thus demonstrating that the epidemic was not striking everywhere all at once. Here the often-cited story of plague's sojourn from the Crimea to northern Italy by way of Genoese sailors is particularly vivid in chroniclers' accounts, and is embellished with details that differ from one chronicle to another. Miraculously surviving Genoese sailors were able to transport the plague in a great refugee odyssey that is best understood as the path of rumours rather than pestilence itself. ${ }^{43}$ Rumours of plague in distant locations swirled around central Italy at the same time, the most famous of which were statistics on plague in Paris almost a year before the disease actually reached there. ${ }^{44}$

\footnotetext{
${ }^{40}$ Before the Black Death, mortality associated with the great conjunction of Mars, Jupiter and Saturn (1345) was assumed to apply for only two years, at the most. That the conjunction was expected to have only short-term pestilence effects, see Goldstein and Pingree, op. cit., note 20 above.

${ }^{41}$ D'Agramont, Regiment, p. 57.

${ }^{42}$ Gentile, op. cit., note 13 above, p. 332: “... quae [pestilentiae] accidit Januae, quae venit de partibus orientalibus et meridionalibus et occupavit omnia loca marium et pervenit ad civitatem Perusinam ...".

${ }^{43}$ Two main stories, with some local embellishments, seem to have circulated around north central Italy during 1348. One was about the fate and itineraries of the Genoese ships and sailors, the other about a day of extraordinary mortality in Paris (where the plague had not yet hit). See the multi-authored 'La peste nera, (1347-1350)', in Ovidio Capitani (ed.), Morire di peste: testimonianze antiche e Interpretazioni moderne della 'Peste nera' del 1348, Bologna, Pàtron, 1995, pp.99-168, esp. pp. 137-43, reviewing the chroniclers' stories of the plague-bearing ships. Such stories do not fit cleanly within medical and religious constructions of a universal plague.

${ }^{44}$ Gilles le Muisit, Chronique et annales, ed. Henri Lemaître, series Société de l' histoire de France, vol. 322, Paris, Renouard, 1906, pp. 196-8. Gilles was abbot of the monastery of St Martin in Tournai, and completely blind from cataracts from August 1346 to September 1351, when an itinerant healer partly cured him. His extraordinary account of news of the plague, local flagellant processions and murderous rampages against the Jews, then finally the plague in Tournai, just happened to coincide with the three years when he wrote a chronicle. See Bernard Guenée, Between church and state: the lives of four French prelates in the Late Middle Ages, trans. Arthur Goldhammer, Chicago and London, University of Chicago Press, 1991, pp. 71-101.
} 


\section{Ann G Carmichael}

Plague had a clear arc, and thus many even in the first-struck Mediterranean region assumed that they could escape by fleeing ahead of its advance. ${ }^{45}$ This pestilence was something that moved, hopefully something that might be outrun. Acknowledging that plague had a path even opened opportunities for historical narrative as its onslaught was unfolding. Observations from non-expert but literate survivors thus did not always fit neatly into medical or religious systems that explained how a universal pestilence could occur. Plague in such narratives became a universal killer, its path describable in merchants' terms. Popular histories today typically privilege many of these stories because they allow us to map epidemics the way we prefer to. For retrospective historical epidemiology, however, this kind of evidence is not very useful.

So powerful was the claim that the "whole world" was affected by the Black Death, that its truth is generally accepted today even in the face of evidence to the contrary. While a few historians have tried to chip away at this assumption, urging further study of places in Europe spared by the plague, ${ }^{46}$ most, on highly imperfect documentary evidence, assume that the pandemic at a minimum spanned the whole of Eurasia. ${ }^{47}$ But recent study of the evidence for plague in Yuan China calls into question the longstanding assumption that the Mongols' Eurasian trade routes brought in plague to northern China. ${ }^{48}$ Similarly the case for plague's extension into the eastern Baltic regions and Russia north of the Caucasus

\footnotetext{
${ }^{45}$ On the early views that plague could be outrun, see Ann G Carmichael, 'SARS and plagues past', in Jacalyn Duffin and Arthur Sweetman (eds), SARS in context: memory, history, policy, Montreal and Kingston, and London, McGill-Queen's University Press, 2006, pp. 50-1. On the plodding diffusion of the plague from Languedoc to Aragon over the spring and early summer of 1348, see Guilleré, op. cit., note 4 above, who provides cautionary evidence for those who believe that the plague actually spread much faster than rat-borne Yersinia pestis could have spread. Dire hunger in the countryside surrounding protected towns collected famished refugees and rats together in the places where grain stores were relatively more secure. Gerona was infected by spread of plague from Perpignan; just sixty-five miles away, Barcelona was just days before infected by maritime commerce.

${ }^{46}$ For example, Zanella further emphasizes that many chronicles make no mention of plague, or do so in the context of stressing other calamities, such as the widely felt earthquake or ongoing food scarcities or endemic wars. Milan, notably, was not stricken violently during the Black Death: see Giuliana Albini, Guerra, fame, peste: crisi di mortalità e sistema sanitario nella Lombardia tardomedioevale, Bologna, Cappilli, 1982, pp. 14-16, who nevertheless believes that plague and St Anthony's fire were conflated. Similarly for Jenks, op. cit., note 34 above, Würzburg is one of the places that escaped the plague altogether, but some there had considerable knowledge of the plague elsewhere.

${ }^{47}$ In less populated regions, it is important to acknowledge the lack of evidence as such. Most intriguing is Charles Halperin's Russia and the golden horde, Bloomington, Indiana University Press, 1985, pp. 83-4, describing the growth of Russian cities in the fourteenth and early fifteenth centuries as a "paradox", if we are to accept the universality of the "plague" pandemic across Eurasia. Similarly Michael Burleigh, Prussian society and the German Order: an aristocratic corporation in crisis, c. 1410-1466, Cambridge University Press, 1984, suggests expansion until the fifteenth century, and Ole J Benedictow, The Black Death, 1346-1353: the complete history, Woodbridge, Boydell Press, 2004, pp. 209-10, 216-24, can find no evidence of the Black Death in the western Baltic regions. Not until the 1410 s, for example, did the Teutonic Knights begin the slow process of economic and military decline within this vast region.

${ }^{48} \mathrm{Li}$ Bozhong, "Was there a "fourteenth-century turning point"? Population, land, technology and farm management', in Paul Jakov Smith and Richard von Glahn (eds), The Song-Yuan-Ming transition in Chinese history, Cambridge, Harvard University Asia Centre, distributed by Harvard University Press, 2003, pp. 134-75. Also see John Dardess, 'Shun-ti and the end of Yüan rule in China', in Denis Twitchett and John K Fairbank (gen. eds), The Cambridge history of China, vol. 6: Alien regimes and border states, 907-1368, ed. Herbert Franke and Denis Twitchett, Cambridge University Press, 1994, pp. 561-86, discussing the collapse of a bloated bureaucracy, in the face of harvest catastrophes, the flight of farmers from north to south China, and mortality stemming from the failure to maintain canals.
} 
The Language of Plague, 1348-1500

mountains has never been strong. ${ }^{49}$ Plague made no headway in south Asia, south-eastern Asia, sub-Saharan Africa and Indonesia, all areas with substantial and quite developed human societies. And plague certainly was not global; the Americas would matter to that claim. Indeed no assertion that the whole world was affected should ever be taken at face value. Yet, the topos of the disease's universality became so dominant in the wake of the Black Death that plague histories still have not been written with the more limited geographical compass of its destruction firmly in mind.

When was the plague topos created? The sense of "universal" plague linked to a view that the whole world was indeed affected probably emerged only as the epidemic waned. Much of the consensus about the magnitude and approximate simultaneity of the epidemic appeared in accounts written after it had passed, quite possibly after the jubilee year of 1350. Francine Michaud's intriguing work on the wills and testaments sworn in Marseilles examined artisans who planned pilgrimages to Rome in 1350, and suggests that many different survivors might have compared their experiences at that point. ${ }^{50}$ If such reaction to loss was widespread, it is possible that the claims for geographical universality in this epidemic coalesced after groups and individuals who participated in this previously planned jubilee learned just how widespread the pestilence was. Certainly pilgrims to Rome would have exchanged accounts of the mortality. We know that the jubilee and a coinciding earthquake in Rome strongly impressed two prolific survivors (Petrarca and Conrad of Megenberg), as well as a Rimini chronicler (Marco Battagli). The latter saw 1350 as a dividing point for his "universal history". 51

\footnotetext{
${ }^{49}$ Uli Schamiloglu, 'The rise of the Ottoman empire: the Black Death in medieval Anatolia and its impact on Turkish civilization', in Neguin Yavari, Lawrence G Potter, and Jean-Marc Ran Oppenheim (eds), Views from the edge: essays in honor of Richard W. Bulliet, New York, Columbia University Press, 2004, pp. 255-79, can offer only evidence for the depopulation in western Asia. Peter Jackson, The Mongols and the west, 1221-1410, Harlow, Pearson Longman, 2005, pp. 290ff, summarizes the evidence for a more southern passage of a great epidemic within the Muslim trade networks. The evidence for substantial incursions of a temporally limited, large-scale epidemic in India is similarly weak: Michael W Dols, The Black Death in the Middle East, Princeton University Press, 1977, pp. 44ff; and, more recently, Stuart J Borsch, The Black Death in Egypt and England: a comparative study, Austin, University of Texas Press, 2005, and Benedictow, op. cit., note 47 above. Cities cannot grow with rural demographic collapse: see the masterful work of John Landers, The field and the forge: population, production and power in the pre-industrial west, Oxford University Press, 2003.

${ }^{50}$ Zanella, op. cit., note 9 above, pp. 50-5; Michaud, op. cit., note 4 above. Pope Clement VI had designated 1350 as a jubilee year in 1343 , long before the plague, thus many pilgrims could have set out believing the pestilence they survived was local or regional.

${ }^{51}$ Battagli, op. cit., note 33 above, pp. 54-5. Marco narrowly escaped death himself: "Quidam minuit me sanguine et sanguis exiens eius faciem tetigit; et in ea die infirmatur et in alia moritur: et pro dei gratia ego evasi." Battagli began his chronicle in the jubilee year; see p. xxiii of Massèra's introduction. Conrad of Megenberg also was clearly writing during the jubilee, trying to advance a different explanation for the universality of this plague; see Dagmar Gottschall, 'Conrad of Megenberg and the causes of the plague: a Latin treatise on the Black Death composed ca. 1350 for the papal court in Avignon', in Jacqueline Hamesse (ed.), La vie culturelle, intellectuelle et scientifique à la cour des papes d'Avignon, Turnhout, Brepols, 2006, pp. 319-32, and Krüger, op. cit., note 23 above; at the beginning of the treatise Clement VI is still Living (Thus it is Written before 1352) and the Years of Plague are Declared to be 1347, 1348, 1349, and "1350 Iubileo" (at p. 863). Petrarca's Association of the Plague, the Earthquake of 1348, and the Jubilee is Prompted by the Earthquake in Rome, See Op. Cit., Note 36 Above, Vol. 2, pp. 99-101 [Book IX, 7, to Louis Sanctus]: "What should I do first, lament or be frightened? Everywhere there is cause for fear, everywhere reason for grief. . . Indeed whoever relates this state of human affairs to posterity, if there be any, will seem to be telling tales ... an unusual tremor about which you probably still do not know shook Rome itself. It was so strong that nothing similar had occurred since the city's founding over two thousand years ago."
} 


\section{Ann G Carmichael}

In Italy, as the plague raged, chroniclers concentrated on wars, the peregrinations of nobles and churchmen, diplomacy, and court politics, so that in many cases references to the plague are either an afterthought or are absent altogether. The surprising absence of descriptions of this pestilence in many strictly contemporary sources is sometimes taken to reveal the utter devastation and havoc it must have created. Because a few vernacular accounts are so harrowing, the assumption is reasonable. But for the most part those people and places that were attacked first could not have known that the plague would carry such virulence. ${ }^{52}$ Because we in our turn know the devastating outcome, what was experienced over days, weeks, months, and years quickly becomes distilled to the plague's quintessence.

The temporal compression of later accounts also makes the plague appear much more rapid in its spread than it actually was, for the epidemic may have spread quickly between well-connected commercial centres, but it diffused more slowly from the port and market cities inland. Italian chroniclers frequently report how prominent people fled to country retreats, only to have the plague catch up with them. Contiguous regions were not affected at the same moment, an important epidemiological feature of the plague, as Robert Sallares has recently shown. ${ }^{53}$ Plague persisted in any given locality no fewer than four or five months, often much longer. It thus does not bear a strong resemblance to any viral epidemic infection that is capable of causing the extraordinary mortality levels produced in the Black Death.

Physicians facing the Black Death tended to omit the temporal duration of plague in a given locality, and barely confronted the difficulties attending the pestilence's geographical spread. And wherever it struck, all were at risk but not all were equally affected. The astrologer Geoffrey de Meaux was in England during the Black Death, and wondered "why it affected some countries more than others, and why within those countries it affected some cities and towns more than others, and why in one town it affected one street, and even one house, more than another, and why it affected nobles and gentry less than other people, and how long it will last". Planetary influences explained why the east, west and north of the world were affected. ${ }^{54}$ Logically, if remote astral causes accounted for a universal pestilence, a plague interval could have been bounded through discussion of the duration of these astral effects. However, concerted effort to do so would have provoked even more difficult questions about the observed geographical and temporal progression of plague within Christendom.

\footnotetext{
${ }^{52}$ Agnolo di Tura, Cronaca Senese, ed. A Lisini and F Iacometti, R.I.S., new ed., vol. 15, part 6, Bologna, N Zaniccheli, 1931-1937, is the best example; see pp. 551-57. Under the year 1347 he reported stories of the Genoese death ships, reports from friends in Pisa of a terrible pestilence there, and a rumour that a few families died of the pestilence in Milan, and their houses were completely sealed up, pp. 552-3. But when he actually saw the pestilence in Siena, beginning in May 1348, words could no longer describe just how horrible it was: "La mortalità cominciò in Siena di magio, la quale fu oribile e crudel cosa, e non so da qual lato cominciare la crudeltà che era e modi dispiatati, che quasi a ognuno pareva che di dolore a vedere si diventavano stupefatti; e non è possibile a lingua umana pareva che la oribile cosa, che ben si può dire beato a chi tanta oribilità non vidde", p. 555.

${ }^{53}$ Robert Sallares, 'Ecology, evolution, and epidemiology of plague', in Lester K Little (ed.), Plague and the end of Antiquity: the pandemic of 541-750, Cambridge University Press, 2007, pp. 231-89, at pp. 255-79.

${ }^{54}$ Geoffrey of Meaux, trans. Horrox (ed.), op. cit., note 15 above, pp. 167-72. Geoffrey accounted for all these cases astrologically, and thus came quite close to a full astrological determinism needed to tackle some of these difficult questions about the non-universal effects of pestilence. This treatise also provides support for those of us who maintain the association of Yersinia pestis with these great plagues: the pestilence wiped out whole families, but at the same time had a patchy distribution at the street, city, and regional level. See Sallares, op. cit., note 53 above, pp. 258-60.
} 
The Language of Plague, 1348-1500

Winds partly explained the problem for some physicians. ${ }^{55}$ Yet, this solution would prompt scepticism, because the prevailing winds are not east to west, nor (north of the Alps) south to north. To some extent the inadequacy of existing explanations in the midst of the multi-year epidemic made the Black Death ineffable for physicians: words failed them because the logic of the plague created serious anomalies within both the Aristotelian physical system and Hippocratic-Galenic medicine. Melissa Chase shows that three generations of physicians at Montpellier and surrounding regions struggled to pinpoint what the ancients had failed to understand and how the taxonomy of pestilences needed to be reconfigured. ${ }^{56}$ Those who confronted this problem concluded that the greatest ancient authorities had no personal experience of comparable great pestilences to draw upon.

\section{Universal Time: Apocalyptical Predictions}

Broadly speaking, there were two different Biblical sources for the expectation that human sin would lead to universal death. One of these was the already mentioned historical precedent: universal human sin had caused a great purging in the Biblical flood. The other was linked to expectations of the end of time, when all creation would enter the era promised in the apocalyptical inclusions of the New Testament gospels, and in the more problematic book of the Revelation of St John. To these were added a miscellany of medieval prophecies, well known and directly linked to flagellant processions north of the Alps. ${ }^{57}$

While the great conjunction of 1345 mattered to philosophers and physicians, those who feared an apocalyptical end of days looked for a different pestilential conjunction: with famine, war, and earthquakes. ${ }^{58}$ The Florentine Giovanni Villani provides a particularly striking example of the first group because he was keen to integrate astrologers' predictions into his view of contemporary Florentine events. Typically, Villani used astrologers'

\footnotetext{
${ }^{55}$ It did, after all, rarely move with the prevailing winds, one of the accommodations within the medical literature for addressing the non-simultaneity of plague occurrences throughout the "whole world". See Naso, op. cit., note 5 above, pp. 374-5, on explanations in terms of winds.

${ }^{56}$ Chase, op. cit., note 14 above.

${ }^{57}$ Here see Smoller, op. cit., note 32 above, pp. 156-87. On the longstanding connections of apocalyptical predictions to pestilence I find these contributions additionally useful: Richard J Clifford, 'The roots of apocalypticism in Near Eastern myth', in Bernard J McGinn, John J Collins and Stephen J Stein (eds), The Continuum history of Apocalypticism, New York and London, Continuum, 2003, pp. 3-29; Robert E Lerner, 'The Black Death and western European eschatological mentalities', Am. Hist. Rev., 1981, 86: 533-52; and Faye Marie Getz, 'Black Death and the silver lining: meaning, continuity and revolutionary change in histories of medieval plague', J. Hist. Biol., 1991, 24: 265-89. Louis Sanctus, writing early in the pestilence (27 April 1348), also notes Biblical descriptions of the ten plagues of Egypt, but I have found no other use of this comparison; see Papy, op. cit., note 36 above, pp. 25-7.

${ }^{58}$ Zanella, op. cit., note 9 above, pp. 49-55. The great earthquake near Villach, felt throughout most of Italy, was particularly important. See Christian Rohr, 'Man and natural disaster in the Late Middle Ages: the earthquake in Carinthia and northern Italy on 25 January 1348 and its perception', Environment and History, 2003, 9: 127-49. In Venice, an inscription at the entrance to the cloister of S. Maria della Carità, written in Venetian dialect, in gold lettering, put the events recently past onto, if not into, the stone, summarizing the earthquake's destruction of bell towers and churches, the beginning of the pestilence forty days later (a nice touch), the death of people from "diverse maladies"- -some spewing blood through the mouth, some showing glanduxe in the groin or under the armpits ("vegnia glanduxe soto li scaii soto e ale lenzene") and others having "lo mal del carbo[ne] per la carne". The long inscription continues with mention of person-to-person spread, abandonment of family, a duration of six months, and huge mortality. The deaths of some of the scola's leaders are recorded, as well as the plenary indulgence. For this and other inscriptions, see Corradi, op. cit., note 8 above, vol. 5, pp. 197ff (at year 1348).
} 


\section{Ann G Carmichael}

predictions retrospectively, to reinforce patterns that he saw in the past. Although his chronicle ends abruptly when he died in the spring of 1348, he knew what dire events astrologers had predicted with the great conjunction of 1345, and was convinced that recent tempests, fires, famine and pestilence in Florence occurred because his fellow citizens had not atoned for their sins. ${ }^{59}$ In other words, astrological tradition supplied a universalizing framework, but Villani was predisposed to accept astrological warnings only as "another mirror of the ways of providence" 60

The earthquake of 25 January 1348 is likely to have fuelled and focused specifically apocalyptical fears more than plague did. This quake was no minor event, for it was felt strongly for hundreds of miles in all directions. The epicentre seems to have been in the Friuli, not in Villach (some miles north in modern Austria), where prominent Black Death chroniclers placed it. ${ }^{61}$ News of it spread much farther than the geographical regions that actually felt the quake. Although his memoirs were not written down until thirty years later, Giovanni of Parma had just recently arrived in Trent (near the epicentre) to assume a post as canon of the cathedral. He vividly remembered that the earthquake lasted for the space of three Pater Nosters and three Ave Marias. ${ }^{62}$ His and other eyewitness accounts have allowed specialists in historical seismology to reconstruct the extent and magnitude of the quake on a kind of "emotional Richter scale". This particular earthquake was one of the greatest in western Europe during the last two millennia, estimated at 8.5 on the physical Richter scale. The subsequent plague may have increased the number of surviving contemporary reports of both events.

Descriptions of plague that mentioned the earthquake may reflect deep-seated conflicts between naturalistic and apocalyptical views of 1348. Placing discussion of earthquakes and astrology in a two-century framework surrounding the Black Death, Laura Smoller notes the pivotal disjuncture that the great plague made, accentuating and reinforcing ambiguities within scholastic astrology. The perspective of modern interdisciplinary work on natural catastrophes, on the other hand, shows that, just as with the unfathomable mortality, there was much more to the earthquake than late medieval scholarly and religious debate could accommodate. ${ }^{63}$ As with the plague, there were facts here that did not fit the available theories and models.

\footnotetext{
${ }^{59}$ Green, op. cit., note 8 above, pp. $38-9$.

${ }^{60}$ Ibid., p. 35. Giovanni died in the Black Death and his brother Matteo, continuing the Florentine chronicle, was disinclined to follow any astrological warnings; he was, as we have seen, strongly convinced that all the calamities unfolding were evidence of God's punishment for humans' sins.

${ }^{61}$ Rohr, op. cit., note 58 above. Still essential is Arno Borst, Il terremoto del 1348: contributo storico alla ricerca sulle catastrofi, Salerno, P Laveglia, 1988. The eyewitness testimonials of the earthquake are discussed on pp. 22-8.

${ }^{62}$ Emanuel Curzel, Lorenza Pamato, and Gian Maria Varanini, 'Giovanni da Parma, canonico della cattedrale di Trento, e la sua cronaca (1348-1377)', Studi Trentini di Scienze Storiche, 2001, 80: 211-39.

${ }^{63}$ The larger context of the perception and management of disasters is finally beginning to receive the attention of medieval and early modern historians. From a cultural perspective, see Jacques Berlioz, Catastrophes naturelles et calamités au Moyen Age, Florence, Sismel, 1998, and François Walter, Bernardino Fantini, and Pascal Delvaux (eds), Les cultures du risque, XVIe-XXIe siècles, Geneva, Presses d'Histoire Suisse, 2006. Neither book addresses the Black Death or the Friuli earthquake, but both provide larger socio-historical context of the perception and management of risks and behavioural responses to disaster. Christa Hammerl's interdisciplinary study of the 1348 earthquake sifts through the historical evidence to separate spread of the news of this quake from the regions where the tremor was actually felt; see the summary of her article online,
} 
After the terrible years had ended, neither a parallel to the Biblical flood nor the apocalyptical end of time explained the significance of this great mortality. Gabriele de' Mussis and Matteo Villani considered the epidemic to have been a stern warning, which (if unheeded) could encourage God to annihilate humanity, the next time sparing none. A climate of anxious expectation reigned. Petrarca, pointing to a vivid example in his own experience of the January 1348 earthquake, remembered when Rome suffered a lesser quake during the jubilee year. "In our early years it would have been a memorable portent if a shepherd's flimsy hut had quaked. But the frequency of calamities has shaken the fear and astonishment out of mortals." ${ }^{64}$ In this minor earthquake of 1350, several Roman churches suffered irreparable structural damage when pilgrims and penitents were present to be terrorized all over again.

Manifestly, the pestilence had not led to other events predicted in apocalyptical texts, and thus the status of this explanatory framework for a great mortality was potentially as problematic as the physicians' astrological claims became when plague returned. ${ }^{65}$ The world did not end, and thus what happened could be more easily accommodated and understood if it were not seen as entirely new. That way, both secular and religious truths about the world held fast. Had modest demographic and economic recovery not followed the Black Death, as it did in most localities, perhaps the plague could have been fitted into an apocalyptical end of days, the narrative structure that made sense during the great mortality. As it was, what place this epidemic had in universal time and history remained unclear. Why were pestilences in the new era so much more punishing than they had been, not only in living memory, but also in historical testimony?

Time, in a temporal/secular/medical sense, was a component of plague experience that absorbed the attention of physicians explaining, and public authorities managing, plagues. An interesting component of Zanella's larger plague topos was the ineffability of plague: many literate survivors claimed that words failed to capture what occurred. Habitual and traditional appeals to ancient authority may have prompted some of the borrowing from descriptions of long-past pestilences, part of the struggle to find words, in part because the experience lay outside received wisdom about predicted, universal time. Ineffability was not, however, precisely the physicians' perception. Instead they found the plague inauditaunheard of. And thus we next move to how survivors characterized what medical experiences were novel, not part of received tradition.

\section{The Emerging Particular within "Universal" Pestilence}

A universal pestilence could not be fully explained within traditional religious and medical frameworks, for 60 per cent of Europeans survived and the lives of those at the bottom of the economic ladder even improved. Furthermore, contemporary observations and reports offered stories of its spread and descriptions of unusual physical symptoms that

in the EC project website for 'Review of historical seismicity in Europe', http://emidius.mi.ingv.it/RGISE/ii_ 20ham/ii_20ham.html.

${ }^{64}$ Petrarca, op. cit., note 7 above, vol. 2, p. 373 (to Guido Sette, Archbishop of Genoa, on how times change).

${ }^{65} \mathrm{I}$ omit here also an important strand in the Black Death topos, unifying medical and lay accounts to some degree: the appearance of unnatural events that served as signs of larger environmental disturbances. Getz, op. cit., note 57 above, sets this material in the foreground, linking it to apocalyptical narratives. 


\section{Ann G Carmichael}

did not flow from larger explanatory models. This section will turn to clinically relatable experiences about recurrent plagues in cisalpine Europe to 1500, because the larger objective of this essay is to return to the current debate about what caused recurrent, demographically punishing plagues of late medieval Europe, focusing on the language of plague.

The Black Death and succeeding plagues offer useful testimony to a modern biomedical perspective, though no narrative evidence will ever prove one retrospective diagnosis or another. The current scholarly assumption is that the first great epidemic was related to the later recurrences of pestilence, because survivors of the Black Death who also witnessed one or more subsequent outbreaks thought they were seeing the same disease. Such claim can made with testimonies from Mediterranean Europe, but may not apply to all of transalpine Europe and the British Isles.

The second pandemic seems to have surprised everyone, dislodging all notions that the 1348 event had been unique. Subsequent plagues were now logically possible and rationally feared, whether one was steeped in the subtleties of Galenic physiology or merely hearing survivors' accounts. Had the plague not returned within a generation-i.e., plague in the 1360s was understood to be the same disease as that of 1348 - discussion of the great mortality might have become more a religious, theological, and (later) historical problem. Perhaps the sense of living in different times would have receded as well. Instead, the plague returned. Learned physicians struggled to fit the plague to existing theory; while eyewitnesses to both epidemics were convinced that the same epidemic disease had reappeared.

\section{"Pestilenza dell' anguinaia": A Lay Consensus}

To support his claim that there was no doubt that bubonic plague had occurred throughout northern Italy in the later fourteenth century, Alfonso Corradi asserted over 150 years ago, before the germ theory of disease and the discovery of the plague bacillus, that the proof was everywhere in the language itself: pestilence was called anguinaia or malattia della glandula, or with "signs" in the inguinal region, in the axilla, or behind the ears. ${ }^{66}$ Corradi's evidence, however, was based more on lay testimonies than on medical observations. Did academic physicians weigh the importance of the bubo to plague differently? And what of the claim that plague was contagious, not the best description today of a fleatransmitted pathogen? Italian chronicles and some medical treatises linked later fourteenth-century plagues to the 1347-50 epidemic through the similarity of the prevailing morbid appearances. Typically they referred to anatomically circumscribed, acute swellings, which, according to Naso, form by contrast only a marginal component of medically informed reports. ${ }^{67}$ But, as I will show in the next section, Latin plague treatises typically include some discussion of the treatment of glandular swellings.

\footnotetext{
${ }^{66}$ Corradi, op. cit., note 8 above, vol. 1, pp. 216-21, and even more insistently with 1371-74, vol. 1, pp. $222-6$. Corradi was also an Italian delegate to the recurring international sanitary congresses of the late nineteenth century, which began to focus on the international control of plague before it was observed in east Asia during the 1890s. Corradi was equally convinced that close attention to the language used by chroniclers could permit him to distinguish epidemics of typhus fever from plague.

${ }^{67}$ Naso, op. cit., note 5 above, pp. 366-7.
} 
Some of the Italian chroniclers bearing witness to the Black Death indeed made much of these buboes in the initial pandemic. Giovanni Villani, for example, heard that the pestilence spreading from Genoa killed its victims in three days, with "certain swellings called gavoccioli" appearing under the arm or in the "anguinaia" (the inguinal region). Florentines nicknamed them ghianducce or bozze. ${ }^{68}$ Guglielmo Cortusio in Padua reported that "the sign of impending death was the appearance of incurable glandulae around the genitalia, or under the arm, or in other parts, together with a venomous fever" ${ }^{69}$ Agnolo di Tura "the Fat", forever remembered for burying five of his children, also reported that Sienese victims had swellings in the groin and armpit. ${ }^{70}$ Most famously Giovanni Boccaccio noted that the plague "began in both men and women with certain swellings either in the groin or under the armpits, some of which grew to the size of a normal apple and others to the size of an egg (more or less), and the people called them gavoccioli". However Boccaccio equivocates at this point, saying that after these swellings appeared, they spread over every part of the body converting the disease to an affliction of livid spots, sometimes even little spots "scattered all around". 71

By the 1360s Italian chroniclers used and reflected a variety of vernacular terms to describe the bodily afflictions particular to plague. Anguinaia was not a new name: inguinaria had been used to describe at least one epidemic in the thirteenth century. But gavoccioli, tincone, ghianducce, faoni, and bozze were distinctive to plague. ${ }^{72}$ An anonymous Pisan chronicler, writing before the city fell to Florence in 1406, could describe the afflictions of 1348 in this way: "Some died of anguinaja, whether a swelling that

\footnotetext{
${ }^{68}$ The whole passage is provided by Zanella, op. cit., note 9 above, fn. 65 . It is interesting that Giovanni Villani does not use the word bubo, which means "owl" in Latin. He did incorporate discussion of bubones when recounting one version of the story of Gog and Magog. That version held that Alexander the Great had devised a way to keep the Tartars, believed to be descendants of one tribe of Israel, in check. They were stupid brutes, who could be fooled into believing that Alexander's army was ever ready to pounce, should they move beyond the high mountains where Alexander placed trumpets. The trumpets cleverly caught the wind when it blew in one unique direction, and thus served as warning. But over time owls built nests in the trumpets, which were silenced, emboldening the heathens. See Green, op. cit., note 8 above, p. 35, and Andrew Runni Anderson, Alexander's gate, Gog and Magog, and the inclosed nations, Cambridge, MA, Mediaeval Academy of America, 1932, pp. 83-5. Some plague tractates, trying to explain the prevalence of plague in autumn when the worst of hot, humid air had passed, fix their attention on the subtle winds coming off mountains.

${ }^{69}$ Cortusio, op. cit., note 35 above, p. 120.

${ }^{70}$ Agnolo di Tura, op. cit., note 52 above, p. 555: "E morivano quasi di subito, e infiavano sotto il ditello e l'anguinaia e favellando cadevano morti."

${ }^{71}$ Giovanni Boccaccio, Decameron, ed. and trans. by Mark Musa and Peter E Bondanella, New York, W W Norton, 1977, p. 4.

${ }^{72}$ An example from the Cronaca Pisana is especially rich: "Chi morì d'anguinaija, che d'uno infiato, che apparìa al ditello; e ad alcuno apparìa alla coscia uno infiato: si chiamava tincone; e chi sputava sangue, e altri sozzi mali ...". This chronicler's description of the return of plague in 1374 reports even more local words for the buboes, col. 1065B: “. . morendone alcuno per dì d'anguinaja, tincone, di soditelli, di faoni, ed altri sozzi mali". See Lodovico Antonio Muratori (ed.), R.I.S., orig. ed., vol. 15, p. 1021. The Grande dizionario della lingua italiana translates "tincone" as an archaic word for abscesses or tumours of venereal origin; figuratively it referred to a disgusting, unwholesome person. The English physician John of Burgundy incorporates the vernacular "bocche" into his treatise: Sudhoff, 'Pestschriften', Archiv für Geschichte der Medizin, 1912, 5: 73-5; the Latin treatise uses gibbus (as a noun): ibid., pp. 75-80. See also the collection from various authors made at the University of Florence in 1969/1970, and reprinted in Capitani (ed.), op. cit., note 43 above, pp. 41-104; pp. 112-117 cull and re-present the texts that mention bubonic swellings. for inguinaria in 1270-71, see Corradi, op. cit., note 8 above, vol. 5, pp. 187-8.
} 


\section{Ann G Carmichael}

appeared under the armpit or one that appeared in the pudenda. They were called tincone. Some spot blood or had other dirty lesions." 73

Italian vernacular sources written during or after the wave of pestilence in the 1360s also identified their plague by reference to its great predecessor. Plague had returned as early as 1358 to the Friuli of north-eastern Italy and some German-speaking regions across the Alps in an itinerary through western Europe that was almost the inverse of its path from 1347 to $1350 .^{74}$ Some, such as Giovanni of Parma and Matteo Villani, emphasized the different groups affected, noting that the second plague initially hit hardest among the weak (children and those long ill). ${ }^{75}$ Both, to their amazement and dismay, observed that many adult men and women died. Matteo lost his life. Others, such as the Franciscan friar Bartholomeo della Pugliola, were more impressed by the magnitude of the 1362 pestilence in Bologna: a "gran moria", "grande e forte", altogether like the "other mortality" in that its sufferers had a glandola in either the axilla or in the groin. Many in Bologna fled to Ferrara and Florence, confident that they could escape through relocation: that lesson about plague was apparently already clear. Meanwhile the epidemic penetrated slowly into the region until January [1362]. Then it began to increase, and finally was so virulent from May to October that it made the second mortality tragically comparable to that in $1348 .^{76}$ Writing in the early fifteenth century Dominico del Maestro Bandino of Arezzo took the symptoms of plague for granted: "they die in a few days with a continuous fever, and suffering glandulas in one of the two emunctories, that is in either the axilla or the inguinal region." 77 He knew first-hand because he was a young child during the Black Death and the only surviving member of his family.

\footnotetext{
${ }^{73}$ In 1374: Cronaca Pisana, in Muratori (ed.), R.I.S., orig. ed., vol. 15, p. 1065B.

${ }^{74}$ Jean Glénisson, 'La seconde peste: l'épidémie de 1360-1362 en France et en Europe', Annuaire-Bulletin de la Société de l'Histoire de France, 1968-1969, pp. 27-38; and Véronique Pasche, 'Les épidémides de peste en Suisse Romande, vers de nouvaux comportements?' in A Paravicini Bagliani and F Santi (eds), The regulation of evil: social and cultural attitudes to epidemics in the Late Middle Ages, Florence, Micrologus, 1998, pp. 125-36.

${ }^{75}$ Curzel, Pamato, and Varanini, op. cit., note 62 above, pp. 236-9, provide a recent critical edition of the canon of Trent's memoir. On the second epidemic Giovanni says (Ibid., p. 238, II . 81-4): "Item millesimo cCLXI fuit alias pestis et mortalitas in universo mundo non minor prima peste, sed eiusdem naturae secundum quantitatem personarum quae illo tempore non erant tot quot in prima peste, sed sic subito et eodem modo quo primo moriebantur." Instead, Matteo Villani was one of many who observed the high mortality among children and adolescents, but claimed vaiuolo, smallpox, took many of them. See M Villani, Cronica, con la continuazione di Filippo Villani, ed. Giuseppe Porta, Parma, Fondazione Pietro Bembo, 1995, vol. 1, pp. 455-6.

${ }^{76}$ Bartholomeo della Pugliola, Historia miscella Bononiensis, ab anno мсIV. usque ad annum мсCCXCIV, ed. Ludovico Antonio Muratori, R.I.S., orig. ed., vol. 18, pp. 464, 466. "In questo anno [1362] fu una gran morìa in Bologna, grande e forte, ed era tutta una malattia, come fu l'altra mortalità, che nasceva una glandola sotto le ascelle, e sotto l'inguinaglia. Molta gente si partì, e andarono a Ferrara, dove non moriva persona. In questi dì incominciò questa mortalità, e andò sino al Gennaijo così leggermente, e venne montando, e finalmente crebbe sì forte di Maggio insino a parte di Ottobre, che quasi si diceva, che era morto tanto di gente come morì nell'altra, che fu in 1348. Di Maggio ancora comminciò la detta mortalità in Ferrara e per la Toscana, grande e forte, e per ogni parte ...". Under the year 1361 (col. 464), della Pugliola noted the plague's beginning in the Piedmont, in the countryside, moving to Milan "e morironvi oltre da 100000 Cristiani". Similarly brutal in Parma, it moved to Rimini and throughout Romagna's towns and "finally everywhere".

${ }^{77}$ Fons memorabilium universi, cited in Muratori (ed.), R.I.S., orig. ed., vol. 15, pp. 123-4: "Egrotantes autem parvis diebus continua febri patiebantur glandulas in altero duorum emunctorium, ascellis scilicet, aut inguine." After noting his mother and father by name, he added, "Quid autem moror in lacrymis? Obierunt illa tempestate fratres, \& omnes sorores meæ. Ego autem cunctorum minimus solus infantulus supervixi in magno gurgite."
} 


\section{Physicians, Anguinaia and Peste}

Medical treatises at the time of the Black Death were not uniform in either format or content, and opened novel and methodologically distinctive possibilities. ${ }^{78}$ But medical plague treatises in the period from 1360 to 1500 soon converged, many adapting the template of medical consilia, or consultations. As is well known, plague treatises typically used a tripartite division of advice, proceeding from a discussion of causes to prevention strategies to cures. The literature on the topic is enormous and typically reinforces a strong sense of conservative, preventive theory and practice. Chase suggested, however, that three generations of academic physicians associated with the university at Montpellier, from approximately 1360 to 1420 , sought to re-categorize plague within medical texts. They created a new category of pestilential fevers, and held plagues to be contagious, caused by poisoning, and associated with particular kinds of apostemes, or swellings.

I therefore examined seventy-two Latin plague treatises written between 1360 and 1500 to ask two simple questions. ${ }^{79}$ First, what proportion of these tractates mention acute bubolike swellings as a feature of plague that required medical attention? Second, what proportion declared the plague to be contagious? Sixty-nine per cent (50/72) included discussion of the management of swellings (variously glandulae, apostemata, tumores, bubones); in some cases bubo management is an extensive component of the section on therapy. Just 25 per cent (25/72) specifically said that the pestilence was contagious, or words to that effect (e.g., that "one can infect many"). I did not consider as "contagion" the standard advice that one should avoid a location where plague existed, including the bedside of the patient, nor did I count commonplace recommendations to avoid crowded places or strangers as a specific reference to contagion. I did include under "contagion", however, any reference to the spread of the disease through contact with a victim. However, if we accept physicians' recommendation of flight as a proxy for contagion, then around 53 per cent of the sample set (38/72) concur. Only one treatise written after 1400 mentions the 1347-50 epidemic, unlike the majority of those from the $1360 \mathrm{~s}, 1370 \mathrm{~s}$ and early $1380 \mathrm{~s} .{ }^{80}$ The overwhelming conclusion here is that most readers and authors of plague treatises expected some discussion of distinctive plague swellings, and that, even long after the living memory of the Black Death had ceased, physicians saw buboes as evidence of plague.

Of all those who noted the resemblance of the second plague to the first, the papal surgeon Guy de Chauliac made the most specific clinical and epidemiological comparison:

After [1360] ... coming back from Germany and northern regions, the mortality revisited us. It began towards the feast of the blessed Michael, with fevers, swellings [bochiis], carbuncles

\footnotetext{
${ }^{78}$ Naso, op. cit., note 5 above, pp. 353-5, 358-60.

${ }^{79}$ Sudhoff, 'Pestschriften aus den ersten 150 Jahren nach der Epidemie des "schwarzen Todes" 1348', Archiv für Geschichte der Medizin, 1910-1925. I first excluded any treatise written before 1360. I then tabulated only Latin (omitting all vernacular) treatises provided in Sudhoff, 'Pestschriften' volumes: 4: 191-222 and 389-424; 5: 36-87 and $332-396 ; \mathbf{6}: 313-379 ; 7: 57-114 ; \mathbf{8}: 175-215$ and 236-89; 9: 53-78 and 117-67; 11: 44-89 and 121-76; and 14: 129-168. I did not retrieve Latin texts which Sudhoff noted, but which were edited and published elsewhere, such as Pietro di Tossignano's important text from 1399.

${ }^{80}$ The exceptional, post-1400 treatise was written by a physician in Lübeck who trained in Montpellier during the 1380s. He also boasts his thirty years' experience with plagues, which is highly atypical: Sudhoff, 'Pestschriften', Archiv für Geschichte der Medizin, 11: 144-63, on p. 148.
} 


\section{Ann G Carmichael}

[carbunculis], and anthrax pustules [antracibus], ${ }^{81}$ gradually, here and there, spread until the middle of 1361. Thereafter it furiously erupted, lasting over the next three months... . It differed from the previous one in that the first struck hardest among the common people, in the second more of the wealthy and noble were affected, as well as an infinite number of children, but women quite lightly. ${ }^{82}$

Some have held that the references to visible lesions on the bodies of plague victims are descriptively ambiguous and refer as often to boils, "spots" (maculae), and pustules as to vague "swellings". ${ }^{83}$ But such vagueness is not a component of plague tractates. A few of them allow "carbuncles" or "pustules" as a companion sign of plague, as Guy de Chauliac does in the example just cited. The language variation in Latin treatises includes glandulae, apostema pestilenciae, ${ }^{84}$ tumor, bubones, ulceralulcus, and even gibbus, but none admits boils or spots. Instead plague treatises discuss pestilential apostemes typically located only in one of the three main "emunctories", what late medieval physicians called the regions that "drained" putrefied matter away from their designated three principal organs (heart, liver, brain). The three emunctories-groin, axilla, and cervical-happen to correspond with the principal sites of acute lymph node engorgement characteristic of Yersinia pestis infection. ${ }^{85}$ Location of a lesion, more than variation in appearances, was important: most authors of plague treatises who discussed surgical or medical treatment of the swellings viewed axillary apostemes and inguinal apostemes as two different disease complexes, to be treated differently. ${ }^{86}$

Of course, we could also emphasize the variety of different symptoms in some popular as well as medical accounts that do not seem so neat and convincing a feature of Yersinia pestis epidemics as are acute bubonic swellings. For Naso, this flexibility in the medieval diagnostic nexus is very important, undermining confidence in any retrospective diagnosis

\footnotetext{
${ }^{81}$ Since there is debate about whether or not he and others could have intended a livid or pustular eruption, I leave some words in the original.

${ }^{82}$ Guy de Chauliac, Inventarium sive chirurgia magna, ed. Michael McVaugh, 2 vols, Leiden and New York, Brill, 1997, vol. 1, p. 119: "Post vero, anno 60\%, pontificatus domini Innocencii sexti anno octo, retrogradando de Alamania et de partibus septentrionalibus, revenit ad nos mortalitas. Et incepit versus festum beati Michaelis, cum febribus, bochiis, carbunculis, et antracibus, paulatine augmentando et aliquociens interpolando usque ad medium anni sexagesimi primi; et postea ita furiose usque ad tres sequentes menses duravit quod non dimisit in multis locis medietatem gencium. Differebat tamen ab alia preterita quia in prima plures recesserunt populares, in secunda vero plures divites et nobiles et pueri infiniti et mulieres pauce."

${ }^{83}$ Samuel K Cohn, Jr, The Black Death transformed: disease and culture in early Renaissance Europe, London, Arnold, 2002, pp. 55-67.

${ }^{84}$ Or: apostema perniciosa, or apostema antrosa, or apostema solidum.

${ }^{85}$ Yersinia pestis is "lymphotropic", which means that this particular pathogen in a mammal finds its way to the lymph nodes, see Joan-Miquel Balada-Llasat and Joan Mecsas, 'Yersinia has a tropism for B and T cell zones of lymph nodes that is independent of the type III secretion system', Public Library of Science: Pathogens (http:// www.plospathogens.org), 2006, 2 (9): 816-28.

${ }^{86}$ The most consistent advice offered in the tractates is that venesection be performed immediately after the patient senses a swelling's beginning, and the vein opened differed according to the site of the bubo. Differences emerge in the subsequent management of the bubo, with some recommending plasters and unguents using theriac, others insisting that theriac should never be used on axillary buboes. Examples from my sample of Latin plague treatises (Sudhoff, 'Pestschriften', Archiv für Geschichte der Medizin, 1910-1923) include extensive discussion of the management of plague buboes: 4: 209-22 (Henry Rybbinis of Wartislava, 1371-72); 6: 344-9 (Giovanni of Santa Sofia, late fourteenth century); 6: 369-73 (John Aygels of Korneburg, early fifteenth century); 7: 102-3 (an anonymous 1430s treatise from Prague); and 14: 158-62 (an anonymous Tractatus de febribus pestilencialibus, compiled around 1450).
} 
we might offer. ${ }^{87}$ Focusing on the fever component of victims' sufferings, physicians tried to place acute pestilential fevers within a larger Galenic nosological classification scheme. How to differentiate putrid from pestilential fevers, as well as plague from other acute fevers, was the important theoretical conundrum that plagues presented. ${ }^{88}$ Naso holds that there was near consensus among later fourteenth-century academic physicians that these were the most important problems to solve, and for this reason, therefore we cannot use their observations to make a secure retrospective diagnosis. Worth equal attention, surely, are the clinical phenomena that they felt obliged to address.

All of the signs of plague were indeed ambivalent to fourteenth-century physicians. Doctors were not able to reach unified and precise clinical criteria useful in formulating a decisive diagnosis of the disease, not even for the most spectacular form: the bubonic. The pulmonary form of plague would have been even more difficult to identify from descriptive accounts, a fact that naturally complicates the use of physicians' observations as a basis for plague's historical epidemiology. But some of the plasticity here is only apparent. Physicians tried to couple their theories to generalizations about clinical observations harvested from a multi-month or multi-year plague epidemic. Moreover, only a few of them, such as Guy de Chauliac, claimed to have acquired extensive first-hand experience treating plague. ${ }^{89}$ Trying to summarize what a plague was, especially after confronting many cases in an epidemic, creates ambiguities. And thus I will return below to a case study of individualized observations during urban plagues in Milan, to examine how knowledgeable academic physicians decided whether or not particular individuals were victims of plague.

\section{Physicians and Temporal Aspects of Plague}

Leading academic physicians, from 1360 to 1500 , carefully explicated the causal problems related to the clinical course of "plague", especially the difference between pestilential fever and plague. Only after 1500 did they begin to worry in any sustained way about the general epidemiological characteristics of "true" plague when compared to other epidemics. Moreover, before the sixteenth century physicians did not confront the overall duration or spatial persistence of plague anywhere in Europe, unlike their lay contemporaries. ${ }^{90}$ Thus we cannot look to late medieval physicians for analysis of this fundamental

\footnotetext{
${ }^{87}$ Naso, op. cit., note 5 above, pp. 366-8.

${ }^{88}$ Dangerous fevers were typically held to arise from corruption of one of the four humours, and because plague could not be securely identified with any one humour, its place within nosological schemes was anomalous.

${ }^{89}$ In my sample of Latin treatises, the ones who claimed first-hand experience with plague were Guy de Chauliac, from Montpellier, Johannes Jacobi, and an anonymous Lübeck physician in 1411.

${ }^{90}$ Modern scientific investigators forged an understanding of Yersinia pestis as an historically important disease only by simultaneous consideration of clinical appearances of victims and environmental perspectives of epidemics. The laboratory linked these two bodies of observations; it did not create them. The combined clinical/ microbiological and epidemiological/environmental synthesis of plague was forged by a global scientific community confronting plague's epidemic spread over a similarly rapid time frame; see Myron Echenberg, Plague ports: the global urban impact of bubonic plague, 1894-1901, New York University Press, 2007. But despite the important later and better-known contributions of Institut Pasteur researchers, the synthesis of microbiology and plague ecology/epidemiology geographically most relevant to recurrent plague in Europe was worked out by Russian and Soviet scientists, from 1895 to the late twentieth century. See Sonia Ben Ouagrham-Gormley,
} 


\section{Ann G Carmichael}

aspect of Yersinia pestis epidemics. Physicians were disinclined to debate why epidemics persisted, just as they glided over the sinuous terrestrial path of plague when attributing the epidemics to celestial events. Moreover, Hippocratic-Galenic medicine regarded epidemics as phenomena with a local (not universal) source, a strong seasonal component, or a group of persons more likely than others to be at risk.

It is not we moderns who try to "square the circle"- to summarize Sam Cohn's view that many medical historians have forced an association between Yersinia pestis and the late medieval pestilences. ${ }^{91}$ Instead, it was late medieval physicians who squared the circle. After the second plague, elite physicians were driven to explain why the disease was so murderous, that is, why it killed so very many people of all ages and social status. We moderns might use the description "extremely virulent", which relates better to late medieval physicians' explanations of venom and poison as causes of plague. In the general popular sense used in chronicles, lethality implied a very short period of time between onset of symptoms and a nearly inevitable death, and physicians concurred with laymen on this point. In survivors' accounts, observed inevitability of death was linked to disbelief at the horrific aspects of the victims' sufferings, one of which was their rapid demise. In managing buboes, the most important consideration for medieval practitioners was to perform blood-letting in the correct location within one day of the bubo's appearance.

Time in plague descriptions thus contains two different components that we might link to modern retrospective diagnosis of the cause of the great epidemic: the length of time that plague victims spent between the onset of illness and their death; and the length of time the plague persisted in a given locality. A particularly striking example here is the testimony of Agnolo di Tura. Like most laymen, Agnolo was more observant of the duration of the epidemic than were physicians. For months he had news of massive epidemics elsewhere, but Siena even sent troops into battle in early 1348. By May Agnolo observed the epidemic unfolding around him. The community created new burial trenches, but many people had to bury their loved ones themselves. Noting that the epidemic mortality persisted at high levels until September, he gave up: "it would be too long to write of it". 92 The post-plague topos, which homogenized discrete and disparate local/survivor experiences, focused on speedy death as a proxy for lethality, and universal pestilence, suppressing evidence where plague did not occur. Plague narratives conflated the events of three years' duration into one great mortality report, just as Agnolo here could no longer even distinguish between the days of a long brutal summer. Medical thinking about the two different temporal components of plague experience evolved quite separately over the next two centuries.

The exceptional personal account by the elite surgeon Guy de Chauliac illustrates how the second plague, 1360-1363, helped him to sort out some of these issues. Guy interrupted the chapter of his Great surgery dealing with thoracic apostemes to recount his memory of the great plague. The mortality began in Avignon in January 1348, and lasted seven

\footnotetext{
Alexander Melikisvili, and Raymond Zilinskas, 'The Soviet anti-plague system: an introduction', Crit. Rev. Microbiol., 2006, 32: 15-64.

${ }^{91}$ Cohn, op. cit., note 83 above, pp. 40-56.

${ }^{92}$ Agnolo di Tura, op. cit., note 52 above, p. 555: “. . . ed era tanta la oribilità, che io scrittore vengo meno a pensare; e però non conterò più. E così durò in fino a settenbre, e sarebe troppo' longo lo scrivare.” With striking archival evidence William Caferro shows how punishing warfare was during the Black Death; see his Mercenary companies and the decline of Siena, Baltimore and London, Johns Hopkins University Press, 1998.
} 
months. During the spring, one mode of the plague predominated-continuous fever with sputum sanguinis. Those stricken in this interval died within three days. The second mode persisted through the remaining five months, also with continuous fever, and with both apostemes and antraces on the (body) exterior, mostly in the groin and the axilla. These sufferers died within five days. The first mode (with bloody sputum) was more contagious, because they not only died very quickly but also quickly transmitted it to others. Next Guy tossed in the obligatory "father did not attend the son, nor the son the father; charity was dead, hope laid low", before turning to his directly personal experience. He fell ill with plague late in the epidemic's course, and to this timing attributed his survival. He then restarted his aside, explained his unwillingness to flee and his attempts to preserve his own health, all before confronting the lethality of the disease: "nevertheless, toward the end of this mortality I was stricken with continuous fever and an inguinal aposteme, and I was so ill for almost six weeks that all my colleagues feared for my life. But the aposteme matured and cured, and through God's justice I survived." 93 The two different temporal components thus enter this rare medical testimonial: the bimodal variation of the plague's character as a multi-month phenomenon, and his own protracted recovery over another period of time.

Modern scholars often conflate the course of a clinical illness with the speed of the epidemic's progression, in part because survivors so vividly characterized an observed rapidity of death, which left those stricken with no time to prepare their souls for eternity. The speed with which the plague overwhelmed victims was, however, the principal feature that exonerated physicians of their inability to cure plague, and consequently time-to-death became an early focus of medical analysis. The swiftness of death after the onset of symptoms led those who addressed this topic to discuss how poisons worked and to recommend aggressive care. The plague's virulence as a poison was then linked to debate about a short list of compound remedies that could be offered as pills, plasters, unguents or electuaries. ${ }^{94}$ The novelty of a specific poison might also explain why ancient authorities offered poor guidance.

Plague came to occupy an anomalous place within both medical and surgical texts. The issue of plague's classification engaged late fourteenth-century academic physicians, and was one to which they would return in the $1500 \mathrm{~s} .{ }^{95}$ By reorganizing the terms of debate,

\footnotetext{
${ }^{93}$ Guy de Chauliac, op. cit., note 82 above, vol. 1, pp. 117, 119: "Incepit autem predicta mortalitas nobis in mense Ianuarii, et duravit per septem menses. Et habuit duos modos. Primus fuit per duos menses, cum febre continua et sputo sanguini, et isti moriebantur infra tres dies. Secundus fuit per residuum temporis, cum febre eciam continua et apostematibus et antracibus in exterioribus, potissime in subassellis et iguinibus, et moriebantur infra quinque dies. Et fuit tante contagiositatis, specialiter que fuit cum sputo sanguinis, quod non solum morando sed eciam inspiciendo unus recipiebat de alio, in tantum quod gentes moriebantur sine servitoribus et sepeliebantur sine sacerdotibus; pater non visitabat filium, neque filius patrem. Caritas erat mortua, spes prostrata. ... Et ego propter diffugere diffamiam non fui ausus recedere; cum continuis timoribus preservavi me cum predictis quantum potui. Nichilominus, versus finem mortalitatis incurri febrem continuam cum apostemate inguinali et egrotavi quasi per sex septimanas, et fui in tanto periculo quod omnes socii mei moriturum me crediderunt. Et maturato apostemate et curato, ut dixi, evasi iussu Dei."

${ }^{94}$ Nicolas Weill-Parot, 'La rationalité médicale à l'épreuve de la peste: médecine, astrologie et magie (1348-1500)', Médiévales, 2004, 46: 73-88, viewed online: http://medievales.revues.org/document884.html.

${ }^{95}$ For examples, Jacques Daleschamps (actually Raymundus Chalmelli de Vivario (of Viviers), who lived in the 1380s at Montpellier), De peste libri tres, Lyons, Gulielmus Rouillius, 1552, p. 11: "Veteribus quidem pestis natura haud prorsus incognita fuit, sed nondum tam comperta, \& explicata, ut ea cognitio ad curationem instituendam
} 


\section{Ann G Carmichael}

physicians shifted quickly from an initial interest in the time-course of plague to an interest in the sequence and value of various therapies. Fourteenth-century physicians thus concentrated on individual clinical cases, and the mechanisms that endangered those in the immediate vicinity of someone stricken with the pestilence. ${ }^{96}$

Observations about the patterns of victimization in specific plague epidemics also had to be reconciled with reasonable models about who should have died. ${ }^{97}$ For example, the papal physician Raymundus Chalmelli of Viviers also tried to correlate his repeated experiences with plague in Avignon, from the 1360s to 1383, with the difficult evidence of who died, what their symptoms were, and what astrological events influenced the character of the epidemics. $^{98}$

\section{Traditional, Preventive Remedies for Plague, 1350-1500}

Some physicians after the Black Death situated plague within a new category of "pestilential fevers". Most authors of plague treatises felt obliged to offer cures and remedies. A nearly obligatory component of plague treatises was the management of the "six nonnaturals", the aspects of an individual's daily life that could be altered to reduce the danger of falling ill. Because nearly half of the treatises that I surveyed held the plague (or plague victims) to be contagious, many also recommended intensive environmental management of one's bedchamber and daily activities. Ill persons and crowded places were dangerous, because, as they sometimes remarked, you never knew who you were talking to. ${ }^{99}$

Flight presented all elites with further dilemmas - knowing where it was safe to go, how to preserve power and property while absent for months, and which travellers and trade presented substantial risk-all of which were increasingly addressed by the invention of novel surveillance and containment strategies of quarantine, household isolation, trade and travel bans, and, eventually, pest houses. Given the extent to which the considerations of the temporal and spatial transit of plague developed from chroniclers' inclusion of plague's duration in a given locality, it is not surprising that the first concerted efforts at restricting the progress of plague through the interruption of trade and travel came only with the third pandemic wave.

sufficeret"; and Johannes Jacobi, Sudhoff, 'Pestschriften', Archiv für Geschichte der Medizin, 5: 56-58, and 17: $16-32$.

${ }^{96}$ For example, the Florentine Nicolo de Burgo's 1382 treatise: "Et summopere cavendum est, ne aer a dictis infirmis ex[s]piratus inspiretur et praecipue in hora mortis alicuius eorum, quoniam tunc ultimata putredo expiratur ab eis." See Sudhoff, 'Pestschriften', Archiv für Geschichte der Medizin, 5: 354-65, at p. 355.

${ }^{97}$ Naso, op. cit., note 5 above, pp. 362-3.

${ }^{98}$ Daleschamps, op. cit., note 95 above, pp. 15-21, and for 1383, pp. 50-2. Chalmelli of Viviers struggled to explain why the ancients described nothing comparable to the plagues he had seen (pp. 11-14); he called the swellings tubercula and struggled to link them to other exanthems - carbunculi, herpetes, phlegmonae, erisipelata, gangraenae (pp. 30-2, 147-50). Of the treatises that I read for this essay, he is the only author to note Pope Gregory the Great's plague. He holds that apostemes without fever are not pestilential, and that plague is a contagious disease, the contagion coming from the breath of the patient. He, too, gives extensive guidelines for management of buboes, pp. 160-8, and at this point begins to call the lesions bubones and glandulae.

${ }^{99}$ See, for example, Sudhoff, 'Pestschriften', Archiv für Geschichte der Medizin, 14: 145: “Cauebis etiam multorum conuersacionem precipue etiam in locis suspectis viuencium, quia vnus frequenter multos inficit". 
But flight presented even greater ethical problems for physicians, as Amundsen showed from a close reading of all the plague treatises, $1348-1500$, that Sudhoff identified. ${ }^{100}$ One interesting solution that authors of these treatises entertained, according to Amundsen, was the permission to abandon a patient with a disease that was hopeless, and for which no cure could be offered. Clarifying the legal obligations of physicians and other urban professionals to their clients became an urgent matter in the early sixteenth century, as waves of pestilence, war and famine reduced northern Italy to circumstances similar to those in the mid-fourteenth century. As Mario Ascheri has shown, this was the surprisingly late moment in which legal tractates on plague first appeared. ${ }^{101}$

The flight response crossed the gulf between the academy and general literate populace. ${ }^{102}$ So too did the notion that universal remedies could be found for plague. Michela Pereira and others have traced the importance of John of Rupescissa's claims of a universal, anti-plague elixir in the decade following the Black Death. ${ }^{103}$ Even by 1361, Guy de Chauliac was emphasizing the universal efficacy of the more traditional remedy theriac in treating plague. Nicolas Weill-Parot has recently stressed that the expansion of alchemical alternatives to traditional Galenic therapy should be seen as a response to the explanatory and practical failures of traditional medicine in the post-plague period. ${ }^{104}$

\section{Plague Diagnosis in Milan, 1452-1522: A Case Study}

Physicians' internal debates focused on a group of concerns related to the causes and clinical management of plague. They debated the nosological categorization of plague, realizing that its place among fevers constituted the greatest problem in diagnosis. They offered traditional advice for the ways that individual clients could manage risks within daily routines. They weighed the utility of a range of compounded cure-alls that were trained against the poison component of plague. Finally they mostly agreed that swellings in three specific bodily locations characterized the disease. These descriptive particulars created a wide variety of local practices to control it. Some plague-control measures involved an input from physicians, but others did not. As Marilyn Nicoud has shown,

\footnotetext{
${ }^{100}$ Darrel W Amundsen, Medicine, society and faith in the ancient and medieval worlds, Baltimore and London, Johns Hopkins University Press, 1996, pp. 289-309; see also Danielle Jacquart, 'Le difficile pronostic de mort (xiv $-\mathrm{xv}^{\mathrm{e}}$ siècles)', Médiévales, 2004, 46: 11-22, online: http://medievales.revues.org/document782.html.

${ }^{101}$ Mario Ascheri, I giuristi e le epidemie di peste (secoli XIV-XVI), University of Siena, 1997.

${ }^{102}$ Pestis manufacta theories during 1348 reinforced popular notions that plague contagion could be carried with impunity from one place to another, and thus that plague could be caused by a substance akin to poisons. On the survival and development of these ideas, see Paolo Preto, Peste e società a Venezia nel 1576, Venice, Neri Pozza, 1978; and William G Naphy, Plagues, poisons and potions: plague-spreading conspiracies in the western Alps, c. 1530-1640, Manchester University Press, 2002.

${ }^{103}$ Chiara Crisciani and Michela Pereira, 'Black Death and golden remedies: some remarks on alchemy and the plague', in Bagliani and Santi (eds), op. cit., note 74 above, pp. 7-39; Michela Pereira, 'Mater medicinarum: English physicians and the alchemical elixir in the fifteenth century', in French, et al. (eds), op. cit., note 6 above, pp. 26-52. Earlier work includes Robert Halleux, 'Les ouvrages alchimiques de Jean de Rupescissa', Histoire littéraire de la France, 1981, 41: 241-84; and, always, Thorndike, op. cit., note 12 above, vol. 3, pp. 347-69.

${ }^{104}$ Weill-Parot, op. cit., note 94 above.
} 


\section{Ann G Carmichael}

Milan's governors were particularly keen to have the physicians' advice and participation, but Milan's efforts were not typical among northern Italian cities of the fifteenth century. ${ }^{105}$

I have presented elsewhere some of the implications of emerging differences between the perception of environmental-epidemiological axes of plague diagnosis, as well as the clinical criteria for a diagnosis of plague that vexed late medieval physicians. ${ }^{106}$ Often public health controls of the disease, particularly during the period before the sixteenth century, developed without physicians because so many prominent ones were, along with their elite patients, absent during the many months of great urban plagues. ${ }^{107}$

A case study from Milan shows how a few generations of learned physicians used the consensus about plague, pestilential fever, and apostemes when they confronted the task of identifying individual cases of plague. In deciding whether a particular individual was a victim of plague, the elastic diagnostic system needed to be reduced to "yes or no"- - or "maybe", for a suspicious death in a household could result in a cautious, short-term quarantine. But some extraordinary records surviving from mid-fifteenth century Milan show that, however polyvalent plague tractates could be in explaining what plague was, physicians could not equivocate repeatedly when they had to assign a brief cause of death.

During the later fifteenth century, elite physicians and surgeons in Milan actually participated in the process of plague diagnosis within an urban context. ${ }^{108}$ Milan's public health office, the Sanita, established a working relationship with the physicians of the city's College of Medicine and those privately employed by the Duke of Milan early in the fifteenth century. By 1450, plague was believed to be determinable from either the story of a patient's last illness, or from the morbid appearances of the cadaver. Physicians working with the public health office persisted in their investigations of new plague cases to the point of viewing cadavers, but I have found no instances of post-mortem dissections performed by these men or this office.

Civic death registers (the Necrologi) survive intermittently over a seventy-year period, from the last six months of a four-year plague, 1449-1452, to a decade-long crisis in the 1520 s, providing detailed reports of death for every person aged over two. I entered into a database all the existing records, comprising around 115,000 deaths, all but around 6000 of which were individual record entries. Although complete annual data survive for only thirty years, sixteen of them before 1500 , much is still possible in understanding plague and other diseases from a modern epidemiological point of view, for one can organize and

\footnotetext{
${ }^{105}$ Marilyn Nicoud, 'Médecin et prévention de la santé à Milan à la fin du Moyen Âge', in Assainissement et salubrité publique en Europe méridionale à la fin du moyen âge-Epoque moderne, Clermont-Ferrand, Presses universitaires Blaise Pascal, 2000, pp. 23-37.

${ }^{106}$ Ann G Carmichael, 'Contagion theory and contagion practice in fifteenth-century Milan', Renaiss. Q., 1991, 44 (2): 213-56; and idem, 'Epidemics and state medicine in fifteenth-century Milan', in French, et al. (eds), op. cit., note 6 above, pp. 221-47.

${ }^{107}$ See chapter 5 of Ann G Carmichael, Plague and the poor in Renaissance Florence, Cambridge University Press, 1986. See also Carlo M Cipolla, Public health and the medical profession in the Renaissance, Cambridge University Press, 1976; idem, Miasmas and disease: public health and the environment in the pre-industrial age, New Haven, Yale University Press, 1992.

${ }^{108}$ In addition to my own publications on Milan's Necrologi, see Nicoud, op. cit., note 105 above, and Albini, op. cit., note 46 above, pp. 158-72.
} 
The Language of Plague, 1348-1500

Table 1

Principal categories of non-plague causes of death in Milanese Necrologi, $1452-1522 \mathrm{n}=81,686$ (with diagnosis)

\begin{tabular}{|l|l|}
\hline General cause of death & $\begin{array}{l}\text { Percentage among all deaths } \\
\text { with cause given }\end{array}$ \\
\hline Fevers & $35.7 \%$ \\
\hline Respiratory symptoms & $14.6 \%$ \\
\hline Gastro-intestinal symptoms & $10 \%$ \\
\hline Rashes, ulcers, fistulas, abscesses & $6.9 \%$ \\
\hline Dropsy & $4.6 \%$ \\
\hline Pestilential fever (not plague) & $3.2 \%$ \\
\hline Trauma & $2.8 \%$ \\
\hline Obstetrical and gynaecological & $2.1 \%$ \\
\hline Senility and other old age & $1.8 \%$ \\
\hline
\end{tabular}

reassemble the records by season, sex, age, and other parameters. ${ }^{109}$ Here I will focus on the plague diagnoses, but Table I provides a breakdown of the commonest causes of death other than plague.

The story of the length, character, and medical management of an illness mattered greatly when a diagnosis was in dispute. The crucial first cases of plague within a household also needed to be supported by defensible evidence, and so physicians identified a number of physical manifestations as potential post-mortem findings of plague. A few examples may serve to introduce the diagnostic axes that signalled the appearance of plague. On 19 July 1505 a boy died suddenly enough for two public physicians, one a hospital physician, the other working for the public health office, to go and view his cadaver. ${ }^{110}$ Noting that there were no worrisome, externally visible signs of plague other than a rash, they admitted that he was quite emaciated and thus more susceptible to the measles. They discounted plague in this case, but cautiously decided to isolate his mother and sisters for a few days.

A plague case looked different to surveillance teams. For example, on 18 February 1483 , a thirty-year-old married woman was seen both before and after death by the two principal

\footnotetext{
${ }^{109}$ For example, catarrh and asthma were effectively the same disease phenomenon (same age distribution, no inter-annual variation, etc.) All the diagnoses before the calamitous $1510 \mathrm{~s}$ and 1520 s were made by university trained physicians, reporting in Latin. Most individuals over the age of two were assigned a cause of death.

${ }^{110}$ Archivio Storico Milano, Fondo popolazione, parte antica. The general contents of the Necrologi are described by Emilio Motta, 'Morti in Milano dal 1452 al 1552', Archivio Storico Lombardo, 1891, 18: 241-86. I will cite individual death reports by date.
} 


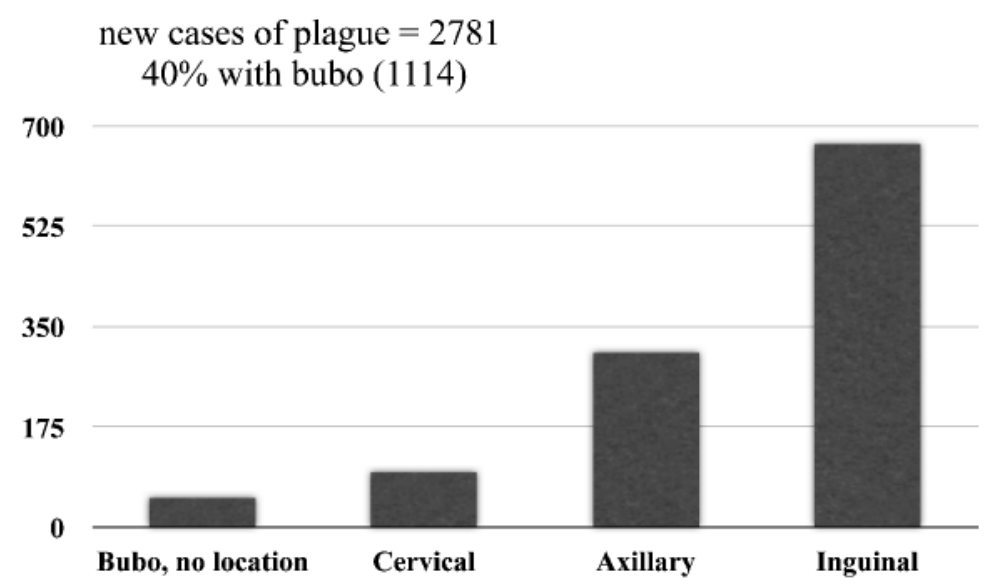

Figure 1: New cases of plague: location of lymphatic swellings as proof of plague.

doctors working for the public health office, one a physician who had served in two plagues already, the other a younger surgeon. When still alive, the woman was terrified, complaining of pain in both sides of the groin "from a dragonzello, as it is called". She was unable to urinate during the last day of her illness. When she died, the surgeon inspected the cadaver "diligently", pronouncing plague the cause of death. He also decided - without giving grounds for his conclusion — that she had an "elongated" uterus.

Any death that occurred within a week after the onset of illness evoked suspicion. Underlying causes—-such as pregnancy, chronic illness, or a history of trauma-were not sufficient in a climate of heightened suspicion of plague. For example, in mid-June 1512, a 23-year-old woman who was said to be four months pregnant fell ill on a Monday with a great headache and also a large tumour in her right axilla, a swelling that stretched to the breast. Two physicians inspected and judged this an instance of plague. Similarly in another plague case, "Savia de Bregnio, servant of Giovanni Pietro Visconti, fifty years old, [died] of a continuous fever, according to master Francesco da Seregnio dei' Medici, but in the judgment of Catelano, from continuous fever with a hard and purplish abscess behind the left ear...".

Swellings in the areas where plague abscesses occurred evoked aggressive diagnostic inquiries, as did discoloration of the skin at the site of a swelling or in a generalized rash. We can see the importance of identifying swellings in the three main areas specified by plague treatises. Forty per cent of newly identified cases of plague cited evidence of one or more characteristic bubonic swellings. In contrast, 18.5 per cent of new cases showed only a pestilential rash (see Figure 1).

Inspecting cadavers one by one was, in the plague treatises that asserted plague's contagion, an exceptionally risky activity for physicians and surgeons. Many of these treatises instructed physicians how to prepare for and move about the sick room. Many recommended that they face outwards, toward a door or window, when in the patient's 


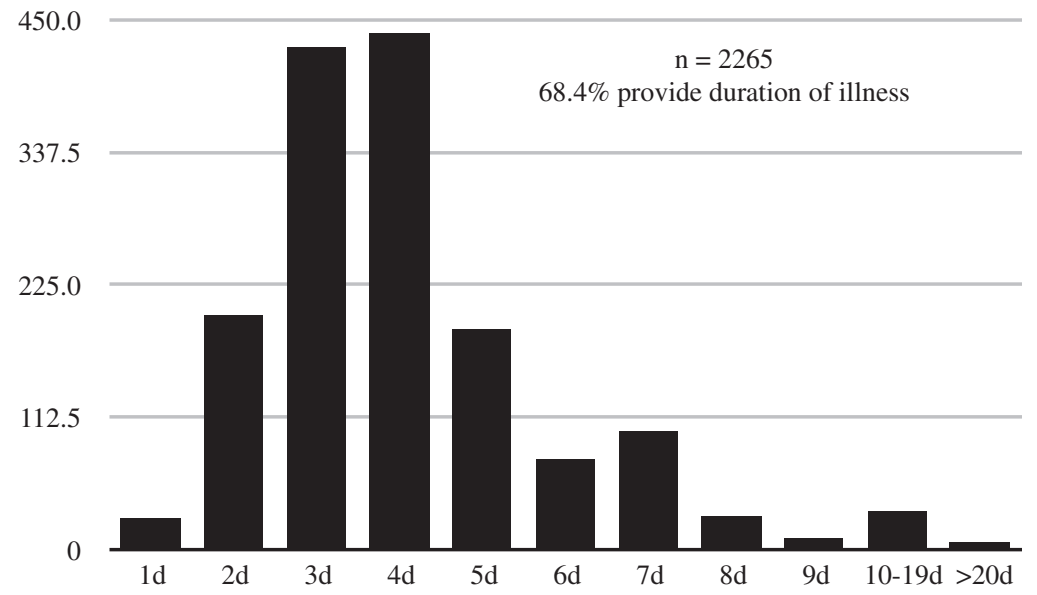

Figure 2: Time ill: assessing new plague cases.

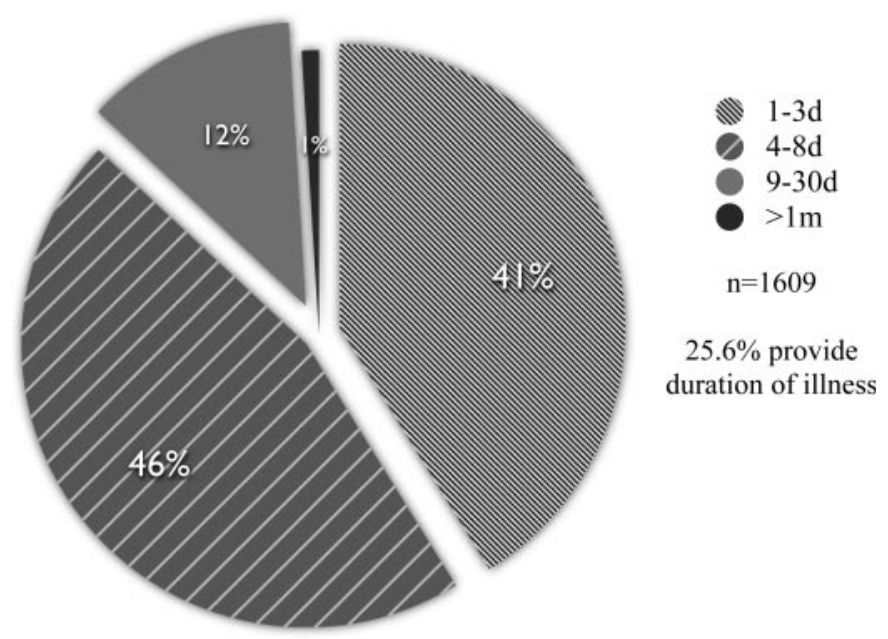

Figure 3: Pestilential fever: length of time ill.

room. One treatise even provided elaborate instructions for covering the urine jar, so that urine analysis could be performed safely out in the street. ${ }^{111}$

Over the seventy years that I surveyed using the Milanese data, the length of time a person had been ill before his or her death became a proxy for plague, as well as the way that plague was separated from "pestilential fever". See Figure 2, which illustrates that the number of days the victim was ill was important to the diagnosis of plague over the entire period. Figure 3 provides a comparative summary of the period victims of pestilential fever were ill before their deaths.

${ }^{111}$ Sudhoff, 'Pestschriften', Archiv für Geschichte der Medizin, 4: 404-6. 


\section{Ann G Carmichael}
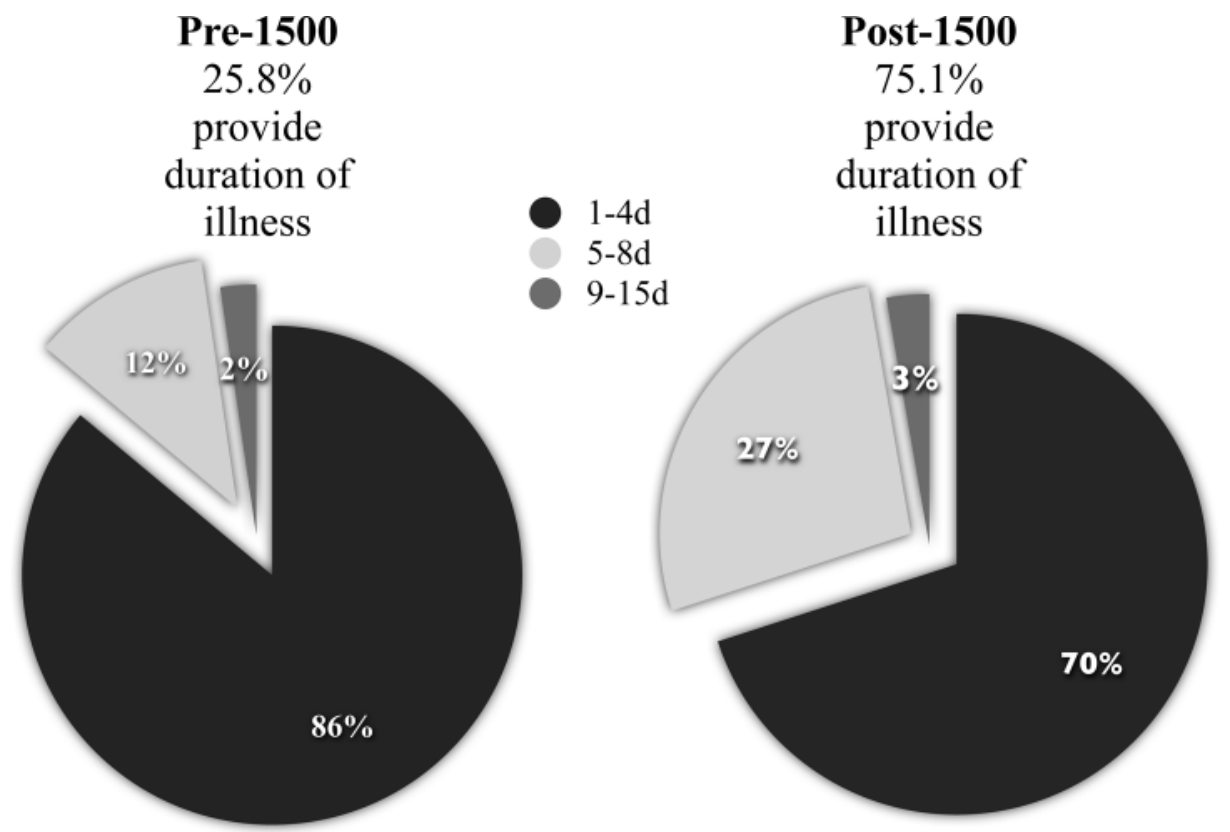

Figure 4: New plague cases, length of time ill: pre-1500 and post-1500.

The plague treatises in my earlier sample survey of seventy-two of Sudhoff's 'Pestschriften' provided little precision on the temporal length of illness in plague, other than to urge blood-letting on the same side as the bubo within the first day it was felt. For Milanese practitioners, by the sixteenth century the length of time a person was ill became the single most important criterion for diagnosing plague. See Figure 4.

Figures 5 and 6 illustrate that the inclusion of any information about the temporal course of an illness treated as plague emerged in the decade after the lazaretto of San Gregorio opened in late 1512, but these data may reflect the sudden subtraction of hospital records from the city death registers. ${ }^{112}$ In other words, fewer people in the records may have been continuously observed by physicians in their last illnesses after the 1510 s.

Occasionally the plague treatises in general circulation provided instruction for the management of some other kinds of lesions, such as carbuncles or pustules, but, oddly, they do not discuss the one other problem that became the next most frightening diagnostic dilemma in Milan: black or violet "measles". To Renaissance physicians the evidence of a non-pustular rash did not in itself signal plague, but merely the body's attempt to rid itself

\footnotetext{
${ }^{112}$ Salvatore Spinelli, La Ca' Grande. L'Ospedale Maggiore di Milano, Milan, Consiglio degli istituti ospitalieri, 1958; and G C Bascapé, 'L'assistenza e la beneficenza a Milano dall'Alto medio evo alla fine della dinastia Sforzesca', in Storia di Milano, Milan, Treccani degli Alfieri, 1953-1962, vol. 8, pp. 391-420. Giuliana Albini, Città e Ospedali nella Lombardia medievale, Biblioteca di storia urbana medievale, University of Bologna Press, 1993, pp. 114-8; and Evelyn S Welch, Art and authority in Renaissance Milan, New Haven, Yale University Press, 1995, pp. 117-43.
} 
- $\mathrm{n}=4257$

- $9.4 \%$ of all deaths provide duration of illness

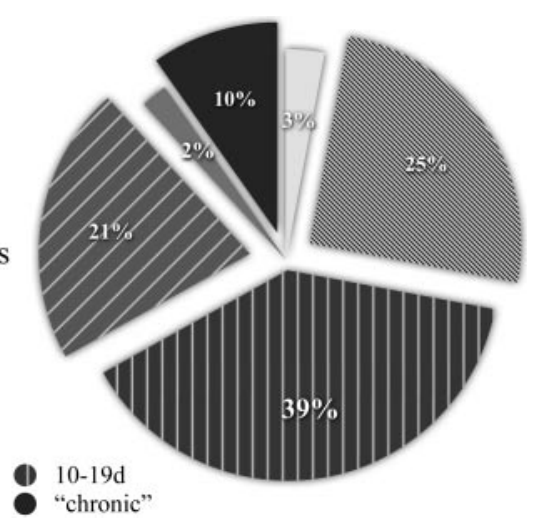

Figure 5: Length of time ill: all reports before 1500.

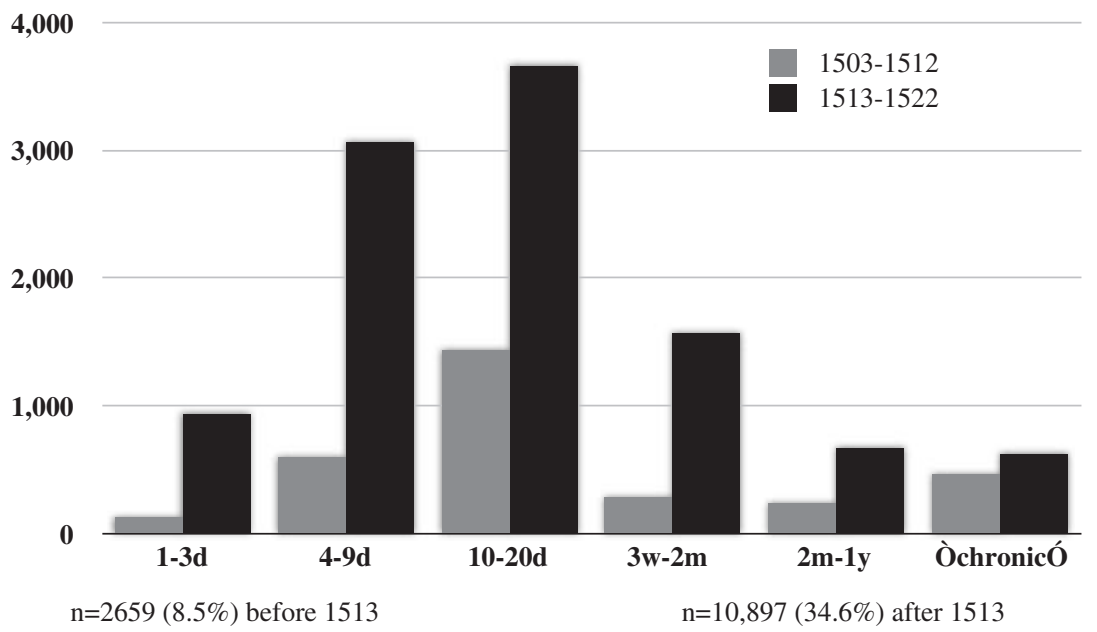

Figure 6: Reporting time ill after 1500: all reports, 1503-1512 and 1513-1522.

of noxious or corrupted humours, expelling the by-products. Similarly vomiting or other excretions served this purpose. Simply seeing a morbilliform rash—red, yellow, black or purple-did not necessarily lead to the conclusion that a specific communicable putrefaction was at work. For example, in May 1478, a 24-year-old man died from a "sanguineous abscess and choleric erysipelas [herpestiomenato] throughout his left arm, poisoned [virulentiato] between six and seven days from an itching vesicle above the artery over the ulna and radius, perforating the palm of the hand, and exuding an acrimonious liquid". Similarly a four-year-old girl, ill for fifteen days, who died on 28 June 1478 with a 


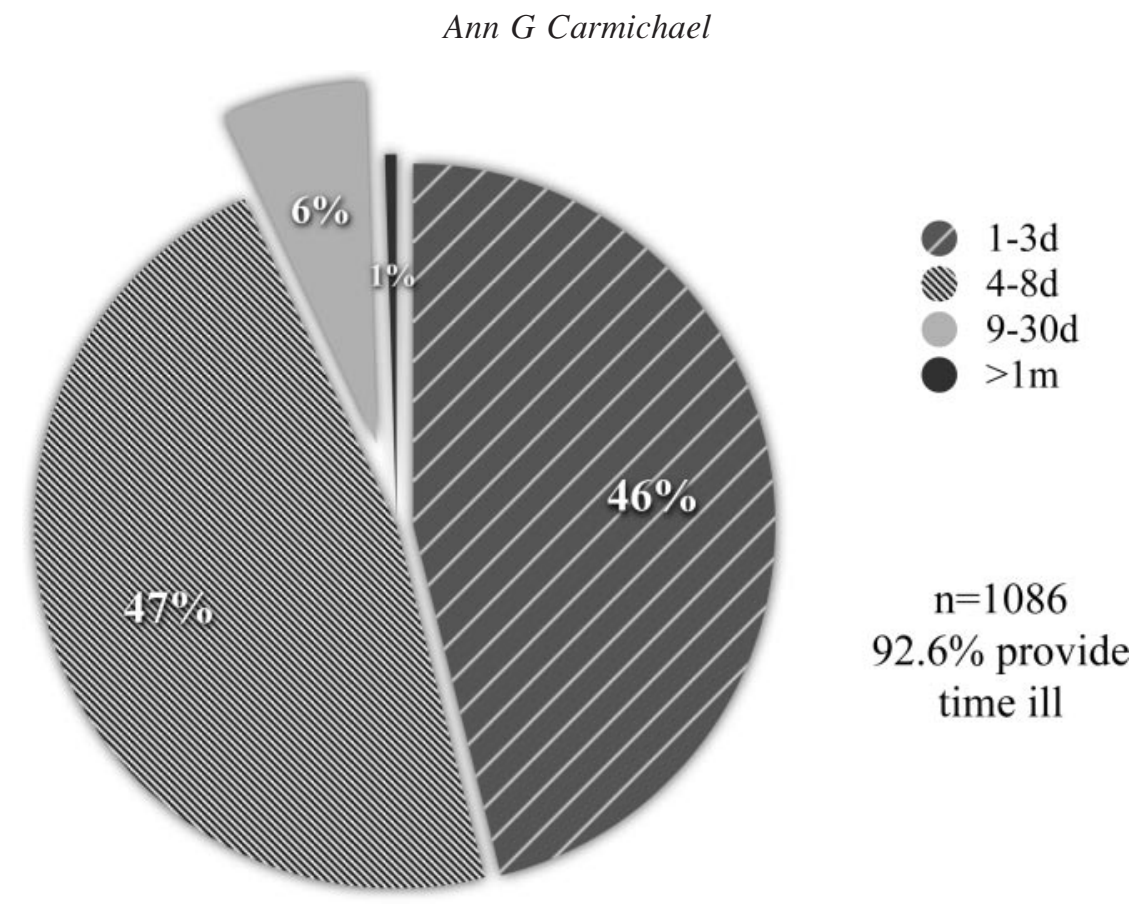

Figure 7: Plague (violet or black) measles: length of time ill.

continuous fever, red measles (morbillis rubeis) and a rash (esere) around her throat and collar, was not judged a case of plague.

A horrific post-mortem appearance also signalled plague. For example, gravediggers reported the death of 65-year-old Francesco Casati on 12 April 1479. Although the victim's household was already a suspected plague focus, his body revealed black, "malignant" measles. Thus the public health office kept the household under surveillance. Seven days later Francesco's 45-year-old wife, Margarita, died, and the post-mortem inspection revealed "an abundance of deep purple measles" (copia morbillorum violaciorum) as well as a bubo (glandula) in her right axilla. Margarita had been sick just four days. While this and other cases cannot be securely identified as bubonic plague in modern biomedical terms, Figure 7 illustrates that the plague treatises available over the previous century would not have been helpful in explaining confusing post-mortem appearances. Nonetheless, the length of time ill, up to a whole week before death, formed a good enough surveillance criterion.

By the beginning of the sixteenth century the symptomatic preconditions for a presumptive diagnosis of plague still included persistent vomiting, relentless headache, and any continuous fever of brief duration. Thus this approach to plague surveillance could be conducted from a safe distance. By the 1510 s, therefore, the records began to designate "dubious cases", signifying households that would be separated for a short period of time to determine if plague was present. In other words there is simultaneously less refinement 
in diagnostic determinations being made, and a tacit acknowledgment that inference from individual appearances at the onset of an epidemic was possible.

The Milanese data add a different picture of late medieval plague from the aggregate descriptions of pestilential disease provided in plague tractates and the much vaguer chronicler summaries that label any crisis mortality as a plague. These data show that urban epidemics were complex and reflected mortality from many different infectious diseases. Nevertheless, the epidemiological picture of modern plague is highly suggestive within these data. While not a proof such as molecular DNA evidence can provide, these data combined with contemporary observers' assertions (repeated generation after generation for over a hundred years) that plague victims had distinctive inguinal, axillary or cervical swellings give us sufficient reason not to dismiss Yersinia pestis as a significant microbial culprit within the Black Death and recurrent epidemics.

\section{Conclusion}

Recurrent plagues in western Europe, from 1350 to the early sixteenth century, were great epidemics unlike those described by physicians of the High Middle Ages. This essay has advanced only two claims. First, eyewitnesses and survivors of great plagues struggled to fit their experiences within their world view. That process required selection and privileging of memories that made sense. Second, Yersinia pestis remains the most likely pathogen to account for the most common clinical appearances in plagues. Obviously all the great epidemics included deaths from many different infectious diseases, for urban sanitation was never a priority and cleanliness did not carry the same meanings that we understand today. ${ }^{113}$

The claim that Yersinia pestis was the perpetrator of many late medieval plagues cannot rest solely on the language of plague. Historical epidemiological analysis and further archaeological studies are necessary. Plague's duration in discrete, localized epidemics, its persistence in local environments, and its general epidemiological parameters make it unlike acute "contagious" viral epidemics. ${ }^{114}$ Also important is the historical framework surrounding plagues of the fifteenth and sixteenth centuries. In the late fifteenth century both medical and civic leaders began to confront how epidemics of plague could be recognized.

All pre-industrial epidemics, including plagues, had multiple infectious diseases exacerbating morbidity and mortality. What is at stake in the retrospective diagnosis of Yersinia pestis as a cause of late medieval European plague is our understanding of the ecological changes that could have permitted that particular microorganism's survival and persistence in western Europe. Plague today persists in the Ukraine and in north Africa, but not in Europe. Equally important, though much better understood historically, are the

\footnotetext{
${ }^{113}$ Douglas Biow, The culture of cleanliness in Renaissance Italy, Ithaca and London, Cornell University Press, 2006.

${ }^{114}$ The age structure of plague mortality within my Milanese data set would be relevant to such a claim. Plague retained its ability to harvest its victims from all age categories, and did not display in Milan any evidence suggesting immunity to the pathogen within the population.
} 


\section{Ann G Carmichael}

demographic and environmental accelerants fuelling late medieval and early modern plagues. ${ }^{115}$ Plague created a legacy of public health mechanisms to deal with recurrent epidemics, which is an indisputable contribution to global history. Even though most of the specific provisions and practices were dismantled and revised later on, through plague management technologies Europeans gradually abandoned the universalizing framework, and came to see plague as a dangerous disease but comfortably localized within persons and places. Above all, the urban poor were its victims. Plague could thus be re-seen as a set of particularizing risks. Those who could avoid risk struggled with the limits of their moral, legal and religious obligations to those who could not avoid risk. On a global scale, we still struggle today with those dilemmas.

\footnotetext{
${ }^{115}$ A useful recent overview is Patrice Bourdelais, Les épidémies terrassées: une histoire de pays riches, Paris, de la Martinière, 2003. See also Jean-Noël Biraben, Les hommes et la peste en France et dans les pays européens et méditerranéens, Paris, Mouton, 1975-1976; Mirko Drazen Grmek, 'Le concept d'infection dans l'antiquité et au moyen âge, les anciennes mesures sociales contre les maladies contagieuses et la fondation de la première quarantaine à Dubrovnik (1377)', RAD Jugoslavenske akademije znanosti i umjetnosti, 1980, 384: 27-54. On the modifications to plague-generated public health provisions, see W F Bynum, 'Policing hearts of darkness: aspects of the international sanitary conferences', Hist. Philos. Life Sci., 1993, 15: 421-34; Peter Baldwin, Contagion and the state in Europe, 1830-1930, Cambridge University Press, 1999.
} 